Original article

\title{
Rhinocerotidae (Mammalia, Perissodactyla) from the middle Pleistocene levels of Grotta Romanelli (Lecce, southern Italy) ${ }^{i s}$
}

\section{Luca Pandolfi ${ }^{\mathrm{a}, *}$, Ivana Fiore ${ }^{\mathrm{b}}$, Mario Gaeta ${ }^{\mathrm{c}}$, Péter Szabó ${ }^{\mathrm{d}, e, f}$, Torsten Vennemann ${ }^{\mathrm{f}}$, Antonio Tagliacozzo ${ }^{\mathrm{b}}$}

\author{
a Dipartimento di Scienze, sezione di Geologia, Università degli Studi Roma Tre, Largo S. L. Murialdo 1, 00146 Roma, Italy \\ ${ }^{\mathrm{b}}$ Servizio di Bioarcheologia, Museo Delle Civiltà, P. le G. Marconi 14, 00144 Roma, Italy \\ ${ }^{\mathrm{C}}$ Dipartimento di Scienze della Terra, Sapienza Università di Roma, p. le Aldo Moro 5, 00185, Roma, Italy \\ ${ }^{\mathrm{d}}$ Environmental Analytical and Geoanalytical Research Group, Szentágothai Research Centre, University of Pécs, Pécs, Hungary \\ e Doctoral School of Chemistry, University of Pécs, Pécs, Hungary \\ ${ }_{\mathrm{f}}^{\mathrm{f}}$ Institut des Dynamiques de la Surface Terrestre, Université de Lausanne, 1015 Lausanne, Switzerland
}

\section{A R T I C L E I N F O}

\section{Article history:}

Received 1st February 2018

Accepted 4 August 2018

Available online 9 August 2018

\section{Keywords:}

Stephanorhinus

Systematics

Morphology

Stable isotope analysis

Taphonomy

Volcanic pumice

\begin{abstract}
A B S T R A C T
The rhinoceros remains collected during the past century in the lower levels XII $(=\mathrm{K})$ and $\mathrm{XI}(=\mathrm{I})$ of the famous Pleistocene locality of Grotta Romanelli (Lecce, southern Italy) are described and compared in detail for the first time. Some remains are referred to Stephanorhinus sp. and others are assigned here to the late early-middle Pleistocene European species Stephanorhinus hundsheimensis based on several morphological characters. Based on its olivine-bearing texture, the volcanoclastic ash sampled from some rhinoceros bones can be referred to the first phase of the Monte Vulture activity (around $630 \mathrm{ka}$ ). The results of the stable isotope analyses suggest that the climate in the lowest levels of Grotta Romanelli could have been more arid than it was at the time of the upper level IX, which is generally referred to the late Pleistocene. In addition, both recent day $\delta^{18} \mathrm{O}_{\mathrm{ppt}}$ values and MAT are very similar to values calculated for levels X and XII, suggesting that the climate at those times may have been close to the Present one, whereas climate in level IX may have been somewhat cooler. The presence of Stephanorhinus hundsheimensis suggests a middle Pleistocene age for the lower levels of Grotta Romanelli, in agreement with the results obtained from the volcanoclastic material.
\end{abstract}

(c) 2018 Elsevier Masson SAS. All rights reserved.

\section{Introduction}

Fossil mammal assemblages are relatively well-documented in southern Italian karsts or cave fillings, in particular in the Apulian area. They are mainly referred to the late Pleistocene (Mirigliano, 1941; Cardini, 1958; De Giuli, 1983; Corridi, 1987; Rustioni et al., 1994; Bologna et al., 1994; Petronio et al., 2007; Pandolfi and Petronio, 2011a; Pandolfi et al., 2017b), with the exception of the lower Pleistocene mammal assemblage of Pirro Nord (Foggia Province; De Giuli et al., 1987; Arzarello et al., 2006) and the middle Pleistocene mammal assemblage of Contrada Monticelli (Bari Province; Mazza and Varola, 1999). Recently, the presence of Holocene karst deposits was also documented in the Salento Peninsula (Cava Donno, Lecce; Pandolfi et al., 2017b). Among others, the cave deposit of Grotta Romanelli (Castro, Lecce)

\footnotetext{
Corresponding editor: Pierre-Olivier Antoine.

* Corresponding author.

E-mail address: luca.pandolfi@uniroma3.it (L. Pandolfi).
}

(Fig. 1(A)) is one of the most famous and studied of the Salento area, today opening about $7 \mathrm{~m}$ above the sea level (Blanc, 1920, 1928; Mastronuzzi et al., 2007). According to Blanc (1920), the platform is marked by potholes (referable to the last interglacial; see Mastronuzzi et al., 2007) partially filled by thin beach deposits with pebbles, pumice and rare marine fossils. Several mammal remains have been recovered from the beach deposits (level XII). Thick slope deposits, represented by red breccia and relatively scarce bones (level XI), cover the level XII (Fig. 1(B)). The stalagmites $\mathrm{H}$ (level $\mathrm{X}$ ) and $\mathrm{F}$ (level VIII) were radiometrically dated to $<69 \mathrm{ka}$ and $40 \pm 3,250 \mathrm{ka}$, respectively (Fornaca-Rinaldi and Radmilli, 1968) (Fig. 1). The sequence of Grotta Romanelli is closed by fine breccia deposits which developed diffusely along the coastal area during the last glacial period (Bella et al., 1958; Vogel and Waterbolk, 1963; Alessio et al., 1964, 1965). The age of the fossiliferous layers underlying the fine breccia deposits has been discussed in literature and has been generally referred to the late Pleistocene by Bologna et al. (1994) and Di Stefano et al. (1992). Nevertheless, the scantly mammal remains collected from the levels XII 

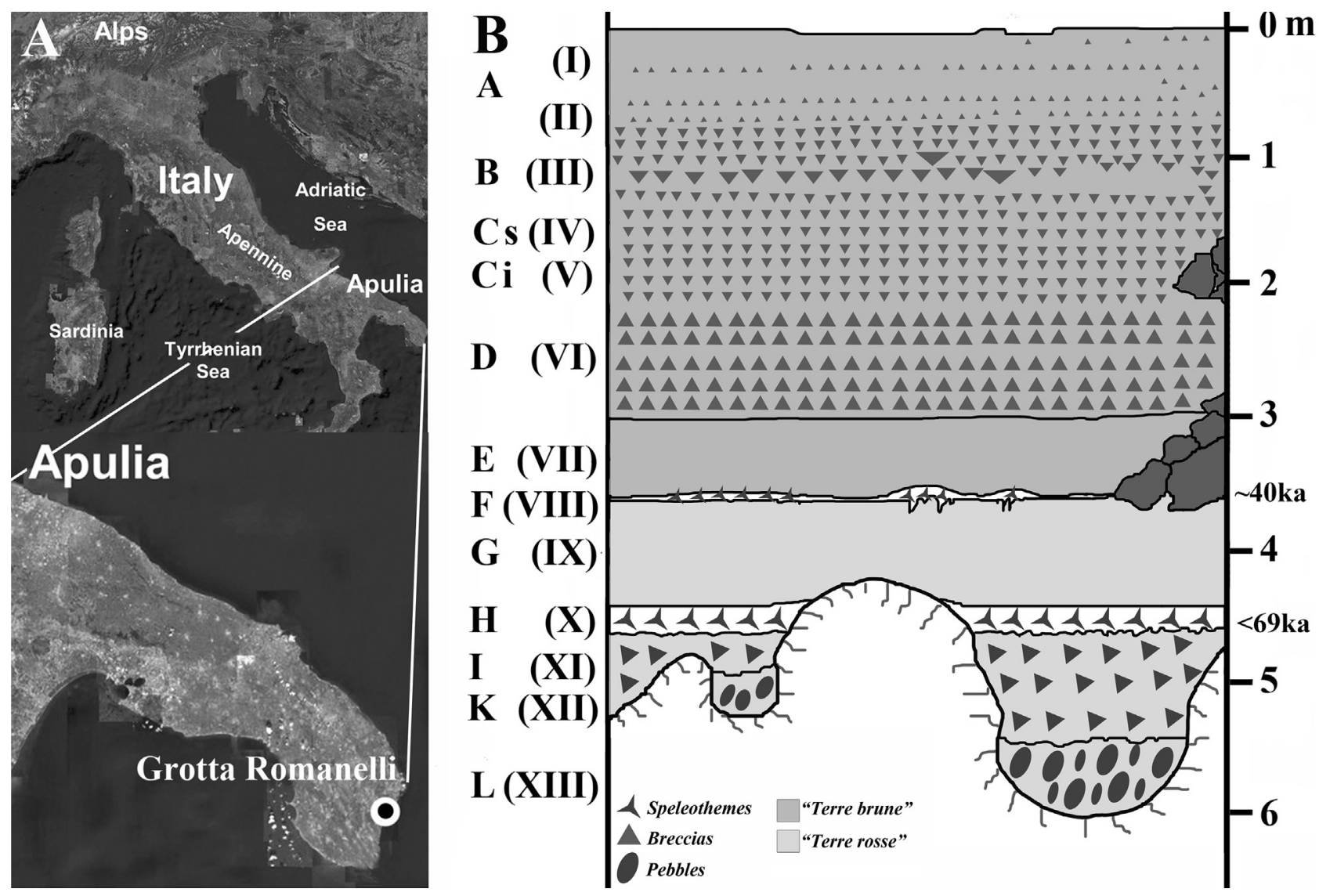

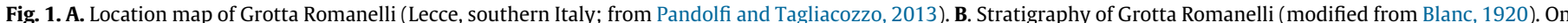

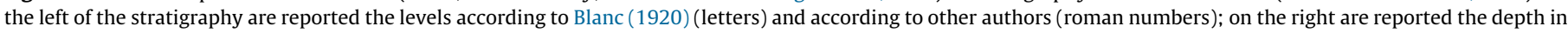
meters of the stratigraphic sequence and the two speleotheme radiometric ages.

(K), XI (I), and X (H) of the cave have never been revised or better investigated after the works of Blanc $(1928,1953)$. During the revision of the present work, Sardella et al. (2018) published a paper on the history of excavations and studies at Grotta Romanelli but they did not add new data about the levels investigated here and on the systematics of the taxa considered. A short note on a third metacarpal of rhinoceros from the stalagmite level X was published by Pandolfi and Tagliacozzo (2013), based on a revision (started on 2012; authorisation n. 0000584, dated 16/02/2012) of the mammal remains from Grotta Romanelli stored in the Museo Nazionale Preistorico Etnografico Luigi Pigorini (MNPELP). Pandolfi and Tagliacozzo (2013) ascribed the remain to Coelodonta, suggesting a Late Glacial age for this level. Nevertheless, Blanc (1953) claimed that the level X included two different strata, one composed of a degradation of the level XI and another composed of a stalagmitic crust. The remain of Coelodonta was probably collected from the stalagmitic crust, as suggested by its high mineralization and its different conservation status compared to other remains collected from level XII and level XI. In addition, unpublished remains of Capra ibex, which suggests cold climatic conditions, have been identified among the material collected from level X (Cassoli, unpubl. data); they are ecologically consistent with the presence of the woolly rhinoceros. Unfortunately, the lower levels XII (K) and XI (I) of Grotta Romanelli were completely excavated during the past century and these deposits do not exist anymore. Therefore, important data on the taphonomy and/or tephrochronology cannot be collected or observed in situ but have to be extrapolated from the fossil bones that are included in the study collection.

The rhinoceros remains from the levels XII (K) and XI (I) of the Grotta Romanelli sequence are described here. They are particularly abundant among the specimens collected from the lower levels, whereas other taxa are scarcely documented or are represented by fragmentary remains. In addition, taphonomic observations and geochemical analyses have been performed to investigate the levels XII (K) and XI (I), their age and palaeoenvironment.

\section{Material and methods}

Institutional abbreviations: HNHM, Hungarian Natural History Museum, Budapest, Hungary; IGF, Museo di Storia Naturale, sezione di Zoologia, Florence, Italy; MfN, Museum für Naturkunde, Berlin, Germany; MGGC, Museo di Geologia Giovanni Capellini, Bologna, Italy; MGPP, Museo di Geologia e Paleontologia, Padua, Italy; MNCN, Museo Nacional de Ciencias Naturales, Madrid, Spain; MNPELP, Museo Nazionale Preistorico Etnografico Luigi Pigorini, Rome, Italy; MPUR, Museo di Paleontologia, Sapienza Università di Roma, Rome, Italy; MSNV, Museo di Storia Naturale, Verona, Italy; MSTB, Museo di Scienze della Terra, Università di Bari, Bari, Italia; NHML, Natural History Museum, London, England; NHMW, Naturhistorisches Museum, Wien, Austria; NMB, Naturhistorisches Museum, Basel, Switzerland.

\subsection{Palaeontology}

The rhinoceros specimens studied here (Table 1 ) are currently stored at MNPELP in Rome; they have been discovered in lower levels XII, XI and X of Grotta Romanelli during archaeological excavations of the 1900s, 1910s, 1950s, and 1960s (Blanc, 1920; Cardini and Biddittu, 1967; Tagliacozzo, 2003). The morphological descriptions of the specimens are based on Guérin (1980), Antoine 
Table 1

List of Pleistocene rhinoceros specimens from level XII and XI of Grotta Romanelli (Lecce, southern Italy) included in this study.

\begin{tabular}{|c|c|c|c|c|}
\hline Anatomical element & Inventory number & Stratigraphic level & Side & Taxonomy \\
\hline Fragment of upper tooth & P7476 & XII & & Stephanorhinus sp. \\
\hline Fragment of lower tooth & P7477 & XII & & Stephanorhinus sp. \\
\hline Fragment of upper tooth & P7484 & XII & & Stephanorhinus sp. \\
\hline Fragment of lower tooth & P7485 & XII & & Stephanorhinus sp. \\
\hline Fragment of lower tooth & P7486 & XII & & Stephanorhinus sp. \\
\hline Fragment of lower tooth & P7487 & XII & & Stephanorhinus sp. \\
\hline Fourth lower deciduous (juv.) & P7423 & XII & $\mathrm{dx}$. & Stephanorhinus sp. \\
\hline Hemimandible (juv.) & P7434 & XII & $\mathrm{dx}$. & Stephanorhinus sp. \\
\hline Scapula & P7435 & $\mathrm{XI}$ & sn. & Stephanorhinus hundsheimensis \\
\hline Radius & P7436 & XII & sn. & Stephanorhinus hundsheimensis \\
\hline Magnum & P7440 & XII & sn. & Stephanorhinus hundsheimensis \\
\hline Pyramidal & P7442 & XII & $\mathrm{dx}$. & Stephanorhinus hundsheimensis \\
\hline Pisiform & P7443 & XII & sn. & Stephanorhinus hundsheimensis \\
\hline Radius (juv.) & P7444 & XII & sn. & Stephanorhinus sp. \\
\hline Humerus (juv.) & P7445 & XII & sn. & Stephanorhinus sp. \\
\hline Semilunar & P7446 & XII & sn. & Stephanorhinus sp. \\
\hline Calcaneum & P7448 & $\mathrm{XI}$ & sn. & Stephanorhinus hundsheimensis \\
\hline Astragalus & P7449 & XII & $\mathrm{dx}$. & Stephanorhinus hundsheimensis \\
\hline Cuboid & P7451 & XII & sn. & Stephanorhinus hundsheimensis \\
\hline Cuboid & P7452 & XII & $\mathrm{dx}$. & Stephanorhinus hundsheimensis \\
\hline Second metatarsal & P7453 & XII & sn. & Stephanorhinus sp. \\
\hline Third metacarpal & P7456 & XII & sn. & Stephanorhinus hundsheimensis \\
\hline Fourth metacarpal & P7459 & XII & $\mathrm{dx}$. & Stephanorhinus hundsheimensis \\
\hline Third metatarsal & P7461 & XII & $\mathrm{dx}$. & Stephanorhinus hundsheimensis \\
\hline Third metatarsal & P7463 & XII & sn. & Stephanorhinus hundsheimensis \\
\hline Fourth metatarsal & P7464 & XII & sn. & Stephanorhinus hundsheimensis \\
\hline Patella & P7465 & XI & $\mathrm{dx}$. & Stephanorhinus hundsheimensis \\
\hline Ulna & P7467 & XII & $\mathrm{dx}$. & Stephanorhinus hundsheimensis \\
\hline Tibia (juv.) & P7468 & XII & $\mathrm{dx}$. & Stephanorhinus sp. \\
\hline Ulna & P7469 & XII & sn. & Stephanorhinus hundsheimensis \\
\hline Fibula & P7470 & XII & $\mathrm{dx}$. & Stephanorhinus sp. \\
\hline Second metacarpal & P7471 & XII & $\mathrm{dx}$. & Stephanorhinus hundsheimensis \\
\hline Humerus & P7474 & XII & $\mathrm{dx}$. & Stephanorhinus sp. \\
\hline First central phalanx & P7488 & XII & & ?Stephanorhinus sp. \\
\hline First central phalanx & P7489 & XII & & ?Stephanorhinus sp. \\
\hline Second metatarsal, fragment & P7490 & XII & & ?Stephanorhinus sp. \\
\hline Second metatarsal, fragment & P7491 & XII & & ?Stephanorhinus sp. \\
\hline Third metacarpal, fragment & P7492 & XII & & ?Stephanorhinus sp. \\
\hline Metapodial indeterminate & P7493 & XII & & ?Stephanorhinus sp. \\
\hline Onciform, fragment & P7494 & XII & & ?Stephanorhinus sp. \\
\hline Second central phalanx & P7495 & XII & & ?Stephanorhinus sp. \\
\hline Second central phalanx & P7496 & XII & & ?Stephanorhinus sp. \\
\hline Third central phalanx & P7497 & XII & & ?Stephanorhinus sp. \\
\hline Third central phalanx & P7498 & XII & & ?Stephanorhinus sp. \\
\hline First lateral phalanx & P7499 & XII & & ?Stephanorhinus sp. \\
\hline First lateral phalanx & P7500 & XII & & ?Stephanorhinus sp. \\
\hline First lateral phalanx & P7501 & XII & & ?Stephanorhinus sp. \\
\hline Second lateral phalanx & P7502 & XII & & ?Stephanorhinus sp. \\
\hline Fragment of pelvis & P7503 & XII & $\mathrm{dx}$. & ?Stephanorhinus sp. \\
\hline Fragment of ulna & P7504 & $\mathrm{XI}$ & sn. & ?Stephanorhinus sp. \\
\hline Third metacarpal, fragment & P7505 & XI & sn. & ?Stephanorhinus sp. \\
\hline Distal articular surface of femur, fragment & P7506 & XI & sn. & ?Stephanorhinus sp. \\
\hline Fourth metatarsal, fragment & P7507 & $\mathrm{XI}$ & sn. & ?Stephanorhinus sp. \\
\hline
\end{tabular}

(2002), and Pandolfi and Tagliacozzo (2015). The studied specimens were morphologically compared to several specimens of Stephanorhinus hundsheimensis, S. kirchbergensis, S. hemitoechus, and Coelodonta antiquitatis from a number of European localities housed in several European collections (HNHM, IGF, MfN, MGGC, MGPP, MNCN, MNPELP, MPUR, MSNV, MSTB, NHML, NHMW, and NMB).

\subsection{Taphonomy}

The lower levels of Grotta Romanelli were completely excavated during the past century and taphonomic data are lacking or scarcely documented. The bone surfaces of 53 rhinoceros specimens have been inspected, 46 of which were collected from the level XII (Table 2). Microscopic analyses of the bone surfaces were carried out using Nikon 1000 stereomicroscopes with a 20-
220 magnification range. In order to identify the nature of the surface alterations on the bones, and to distinguish traces of human activity from animal-derived traces, as well as trampling modifications from the alterations produced during the excavation, reference was made to specific taphonomic analyses in the literature (Binford, 1981; Lyman, 1994; Fisher, 1995; Gaudzinski, 1999; Pirrone et al., 2014; Pokines and Symes, 2013). The degree of combustion was evaluated following Shipman et al.'s (1984) and Stiner et al.'s (1995) methodology. Bökönyi's (1970) approach has been followed to evaluate species abundance and estimate the minimum number of individuals (MNI).

\subsection{Stable isotope measurements}

The sampling, pre-treatment, and measurement methods adopted here are the same as in Kovács et al. (2015). Enamel 
Table 2

Minimum number of individuals (MNI) and number of identified specimens (NISP) estimated for the Pleistocene rhinoceros remains of the lower levels of Grotta Romanelli (Lecce, southern Italy).

\begin{tabular}{lrrrr}
\hline Anatomical element & XII & XI & X & Total \\
\hline Hemimandible & 1 & & 1 & 2 \\
Teeth & 7 & & 3 & 10 \\
Long bones - anterior leg & 6 & 2 & & 8 \\
Carpus & 5 & & & 5 \\
Metacarpus & 4 & 1 & & 5 \\
Long bone - posterior leg & 3 & 2 & & 5 \\
Tarsus & 3 & 1 & & 4 \\
Metatarsus & 6 & 1 & & 7 \\
First central phalanx & 2 & & & 2 \\
Second central pahalnx & 2 & & & 2 \\
Third central phalanx & 2 & & & 2 \\
First lateral phalanx & 3 & & & 3 \\
Second lateral phalanx & 1 & & & 1 \\
Metapodial indeterminate & 1 & & $\mathbf{4}$ & $\mathbf{5 7}$ \\
Total NISP & $\mathbf{4 6}$ & $\mathbf{7}$ & $\mathbf{1}$ & $\mathbf{8}$ \\
NMI & $\mathbf{5}$ & $\mathbf{2}$ & & \\
\hline
\end{tabular}

was sampled along a vertical line parallel to the length axis of specimens (typically $\sim 1-2 \mathrm{~cm}$ ) with a Dremel diamond-studded drill (Tafforeau et al., 2007; Metcalfe and Longstaffe, 2012). Sample powder was pre-cleaned following Koch et al.'s (1997) method. After pre-cleaning, a $\sim 2 \mathrm{mg}$ subsample was used for the carbonate isotope measurements. Concerning $\delta^{18} \mathrm{O}_{\mathrm{PO} 4}$ analyses on dissolved samples, phosphate ions were precipitated as silver phosphate (Dettman et al., 2001; Kocsis, 2011). The carbon and oxygen isotopic compositions of structural carbonate were measured using a Finnigan MAT Delta Plus XL mass spectrometer equipped with a GASBENCH-II preparation unit. Carrara marble in-house standards $\left(\delta^{18} \mathrm{O}=-1.70 \%\right.$ VPDB; $\quad \delta^{13} \mathrm{C}=2.05 \%$ VPDB $)$ were analysed in the same sequence than samples and used for data correction. The reproducibility of the in-house standard was less than $0.1 \%$ o $(1 \sigma)$ for both oxygen and carbon isotope compositions. For the phosphate $\delta^{18} \mathrm{O}$ analyses, silver-phosphate was analysed via reduction with graphite in a TC/EA (high-temperature conversion elemental analyser) coupled to a Finnigan MAT Delta Plus XL mass spectrometer according to the values and method given in Vennemann et al. (2002). The results were corrected to inhouse $\mathrm{Ag}_{3} \mathrm{PO}_{4}$ phosphate standards (LK-2L: $12.1 \%$, and LK-3L: $17.9 \%$ ) which showed standard deviations $(1 \sigma)$ lower than $\pm 0.3 \%$ during the measurements. The carbon and oxygen isotope compositions are expressed relative to the VPDB (Vienna Pee Dee Belemnite) and VSMOW (Vienna Standard Mean Ocean Water) standards, respectively. The isotope analyses were conducted in the stable isotope laboratory of the University of Lausanne. For the interpretation of the $\delta^{13} \mathrm{C}_{\mathrm{CO} 3}$ results, the modern equivalent diet composition $\left(\delta^{13} C_{\text {diet,meq }}\right)$ can be calculated with the equation of Domingo et al. (2013):

$\delta^{13} C_{\text {diet, meq }}=\delta^{13} C_{\text {leaf }}+\left(\delta^{13} C_{\text {modernatmCO2 }}-\delta^{13} C_{\text {ancientatmCO2 }}\right)$

where the ancient atmosphere is referred to $-6.5 \%$ (Tipple et al., 2010) and the modern atmosphere value was referenced to $-8 \%$

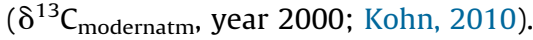

Teeth of large ( $>100 \mathrm{~kg}$ ), obligate drinking mammals record an average oxygen isotope composition of ingested water $\left(\delta^{18} \mathrm{O}_{\mathrm{w}}\right)$ allowing for the computation of $\delta^{18} \mathrm{O}_{\mathrm{w}}$ values (Ayliffe et al., 1992; Bryant and Froelich, 1995; Koch, 1998). In this study the $\delta^{18} \mathrm{O}_{\mathrm{w}}$ values were calculated with two different general equations: Kohn and Cerling (2002), and Amiot et al. (2004).

The analysed material is listed in Table 3. It includes remains from level XII, X and IX in order to evaluate possible differences in
Table 3

List of Pleistocene rhinoceros specimens from Grotta Romanelli (Lecce, southern Italy) sampled for isotopic analyses and specimens from which volcanoclastic material has been collected.

\begin{tabular}{lll}
\hline \multicolumn{2}{c}{ List of specimens for isotopic analyses } \\
\hline Anatomical element & Inventory number & Stratigraphic level \\
\hline Fragment of third upper molar & P7475 & IX \\
Fragment of upper tooth & P7476 & XII \\
Fragment of lower tooth & P7477 & XII \\
Fragment of upper tooth & P7478 & X \\
Fragment of upper tooth & P7479 & X \\
Fragment of upper tooth & P7480 & X \\
Tooth fragment & P7481 & IX \\
Fragment of lower tooth & P7482 & IX \\
Fragment of lower tooth & P7483 & IX \\
Fragment of upper tooth & P7484 & XII \\
Tooth fragment & P7485 & XII \\
Tooth fragment & P7486 & XII \\
Fragment of lower tooth & P7487 & XII
\end{tabular}

List of sampled specimens for volcanoclastic analysis

\begin{tabular}{lll}
\hline Anatomical element & Inventory number & Stratigraphic level \\
\hline Radius (juv.) & P7444 & XII \\
Humerus & P7474 & XII \\
Mandible (juv.) & P7434 & XII \\
Ulna & P7467 & XII \\
\hline
\end{tabular}

enamel composition in the different levels and to evidence potential variations in palaeoenvironmental parameters.

\subsection{Volcanoclastic material}

The presence of volcanoclastic material (in particular pumice) within the thin beach deposits with pebbles and rare marine fossils (level XII) was already reported by Blanc (1920), but this material had never been studied or analysed in details except for a paper published in the 1950s (Lazzari, 1955). Unfortunately, no sample of the volcanoclastic material had been collected by past scholars; therefore, it has been detected on some bones included in this study.
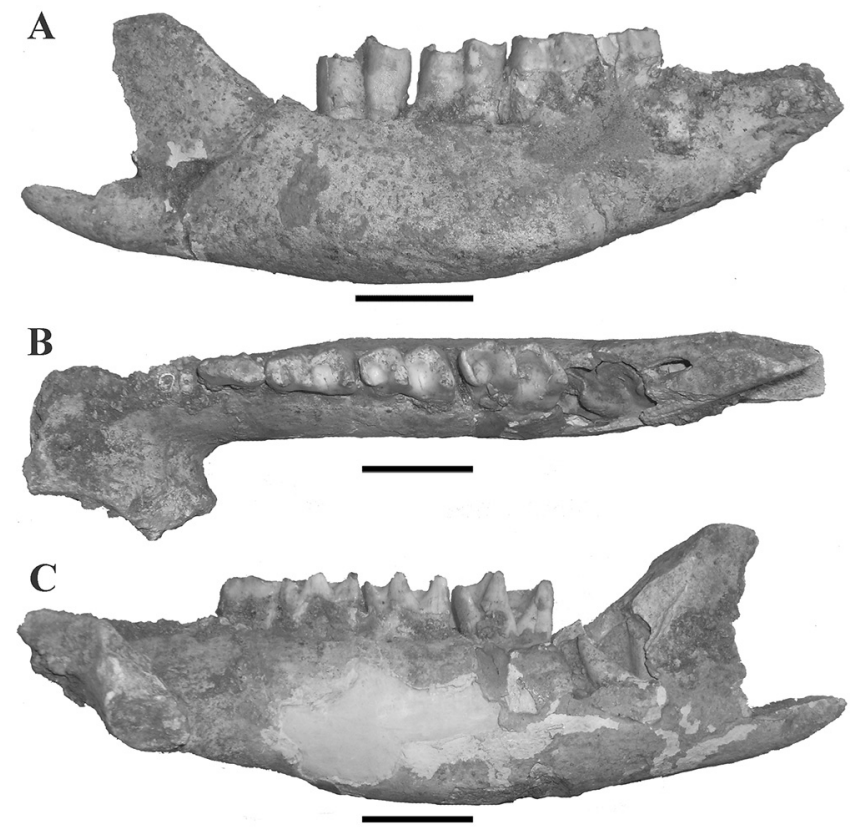

Fig. 2. Hemimandible (P7434) of Stephanorhinus sp. from the level XII of Grotta Romanelli (Pleistocene; Lecce, Southern Italy) in buccal (A), occlusal (B) and lingual (C) views. Scale bars: $5 \mathrm{~cm}$. 
The volcanoclastic matrix present in the internal and external parts of the bones (Table 3 ) was carefully removed using a thin blade from four rhinoceros bones from level XII. The sediment was inspected under a binocular microscope, separating the different components (e.g., minerals, rock fragments) which were mounted on the stabs. Morphoscopic structures were observed at the Dipartimento di Scienze della Terra, Sapienza-Università di Roma, using a FEI Quanta 400 SEM. The composition of phases present in the selected pumice clast was determined at CNR-IGAG (Rome, Italy) using a CAMECA SX50 electron microprobe equipped with five wavelength-dispersive spectrometers (WDS) employing a $15 \mathrm{kV}$ accelerating voltage, a $5 \mathrm{nA}$ beam current, and a $0-10 \mu \mathrm{m}$ beam diameter. Natural and synthetic standards, as well as the ZAF correction scheme, were used.

\section{Systematic palaeontology}

Class Mammalia Linnaeus, 1758

Order Perissodactyla Owen, 1848

Family Rhinocerotidae Gray, 1821

Subfamily Rhinocerotinae Gray, 1821

Tribe Rhinocerotini Gray, 1821

Genus Stephanorhinus Kretzoi, 1942

Type species: Stephanorhinus etruscus (Falconer 1868) from the early Pleistocene of Upper Valdarno (Italy).

Referred species: Stephanorhinus kirchbergensis (Jäger, 1839), Stephanorhinus hemitoechus (Falconer, 1859), Stephanorhinus hundsheimensis (Toula, 1902), Stephanorhinus yunchuchenensis (Chow, 1963), Stephanorhinus jeanvireti (Guérin, 1972), Stephanorhinus lantianensis ( $\mathrm{Hu}$ et $\mathrm{Qi}, 1978$ ), maybe "Stephanorhinus" miguelcrusafonti (Guérin et Santafé-Llopis, 1978), and with uncertainty Stephanorhinus? africanus (Arambourg, 1970).

Stephanorhinus hundsheimensis (Toula, 1902)

Holotype: Almost complete skeleton, including partial skull and mandible (2013/0282/0001), housed at the Natural History Museum, Wien (Austria).

Type locality and horizon: Hundsheim (Lower Austria, Austria), early middle Pleistocene (Marine Isotopic Stage 15 or 13).

Occurrence: From the late early Pleistocene to the early middle Pleistocene in Europe. S. hundsheimensis (= Dicerorhinus etruscus brachycephalus) is reported in Western Asia (Caucasus) during the late middle Pleistocene (Guérin, 1980; Baryshnikov and Guérin, 1986).

Referred Specimens: Scapula (P7435), radius (P7436), two fragments of ulna (P7467, P7469), magnum (P7440), pyramidal (P7442), MCII (P7471), MCIII (P7456), MCIV (P7459), patella (P7465), astragalus (P7449), calcaneum (P7448), two cuboids (P7451; P7452), MTIII (P7461), and MTIV (P7464).

\section{Description:}

Scapula (P7435). Only a distal portion of scapula is preserved. In articular view, the supraglenoid tubercle is well-developed and the coracoid process is relatively small. The glenoid cavity is ovoidal, not completely articulated and its caudal border is wider transversally than cranial one.

In $C$. antiquitatis, the glenoid cavity is usually sub-rectangular and its lateral border is regularly convex; the coracoid process is small. In S. kirchbergensis, the glenoid cavity is sub-rectangular, the supraglenoid tubercle is well-separated from the glenoid cavity and the coracoid process is developed. In S. hemitoechus, the supraglenoid tubercle is rounded and not well-separated from the glenoid cavity which is ovoidal but completely articulated. In S. hundsheimensis the glenoid cavity is ovoidal in shape (Lacombat, 2005).

Radius (P7436). The radius is represented by a proximal epiphysis slightly damaged on the medial articular surface
(Fig. 3(A1)). In dorsal view, the coronoid process is prominent and the bicipital tuberosity is represented by a rounded relief (Fig. 3(A2)). In palmar view, the palmar proximal apophysis is damaged and the two articular surfaces for the ulna are badly preserved. In proximal view, the lateral articular surface is squarish (Fig. 3(A1)), the dorsal border of the epiphysis appears rather straight. The angle between the palmar border of the lateral articular surface and that of the medial one is obtuse.

In S. hemitoechus the proximal epiphysis, compared to P7436, is characterised by a more acute angle between the palmar borders of the proximal articular surfaces, by a convex or slightly convex dorsal border of the epiphysis, and by a less marked coronoid process in dorsal view. The studied specimen differs from C. antiquitatis in which the lateral tubercle on the proximal epiphysis is larger; the proximal border of the lateral articular surface is longer than P7436 in dorsal view; the coronoid process is relatively smaller than in P7436, with a wavy dorsal border of the proximal epiphysis in proximal view. Moreover, in S. kirchbergensis the lateral tuberosity on the proximal epiphysis is large, the coronoid process is small in dorsal view, the lateral articular surface is longer and more rounded than P7436 in proximal view, and the palmar angle between the proximal articular surfaces is less obtuse than P7436. S. hundsheimensis resembles the specimen from Grotta Romanelli in having, in proximal view, a more obtuse angle between the palmar borders of the medial and lateral articular surfaces than other Pleistocene species, a rather straight dorsal border of the epiphysis in some specimens, and a lateral articular surface relatively well-developed and less rounded. This radius is therefore attributed to $S$. hundsheimensis.

Ulna (P7467, P7469). A fragment of the proximal epiphysis of an ulna is preserved (P7467). In medial and lateral views, the articular surface is not very concave. In dorsal view, the articular surface is not very wide transversally. The development of the proximal articular surface is a diagnostic character to distinguish $S$. hundsheimensis from $S$. hemitoechus according to Lacombat (2005); the latter species displays a more developed and concave articular surface compared to $S$. hundsheimensis and to the studied specimen, which is therefore assigned to Toula's species.

A distal epiphysis of ulna is also preserved (P7469; Fig. 3(B)). In lateral view, the articular surface for the pyramidal extends upwards on the lateral face contrary to that of S. hemitoechus. In medial view, the articular surface is less developed than in S. hemitoechus. In distal view, the distal articular surface is less developed than in $S$. hemitoechus; its lateral border is convex whereas the medial one is concave (Fig. 3(B)). As in P7469, in S. hundsheimensis from Hundsheim and Untermassfeld the distal articular surface is not too extended upwards in lateral view. The ulna of S. kirchbergensis used for comparison lacks the distal epiphysis, which prevents any morphological comparison with other specimens. However, the bones of S. kirchbergensis are generally larger than those of other species of the same genus (Fortelius et al., 1993). Accordingly, this specimen is doubtfully referred to $S$. hundsheimensis.

Magnum (P7440). In dorsal view, the dorsal face of the bone is pentagonal in shape (Fig. $3(\mathrm{C})$ ). The proximal border is relatively short, whereas the border of the articular surface for the unciform is long. The distal border of the dorsal face, which was articulated with the third metacarpal, is very convex. The medial border of the dorsal face is not very extended medially.

In dorsal view, P7440 differs from S. kirchbergensis in being less medially extended and in having a shorter proximal border. In S. hemitoechus, the articular surface for the unciform is shorter in dorsal view, whereas the proximal border is longer; the border is less convex distally. The anterior face of the specimen from Grotta Romanelli morphologically resembles the anterior face of the magnum of S. hundsheimensis from Hundsheim. 

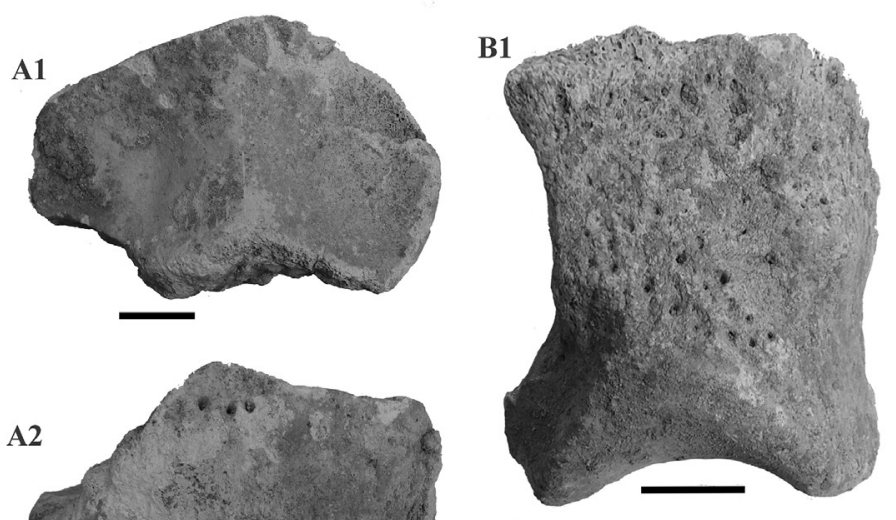

C
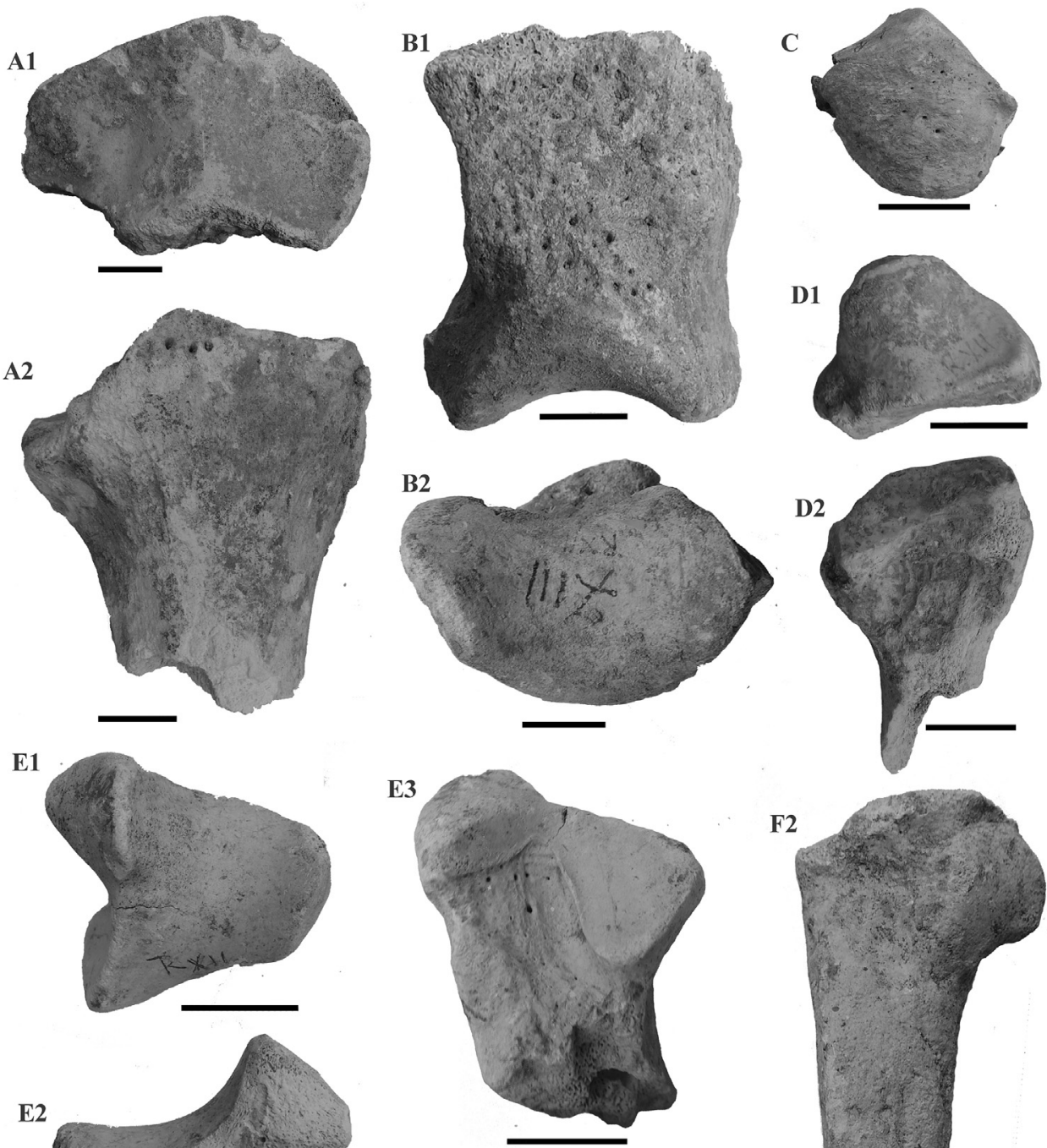

D2
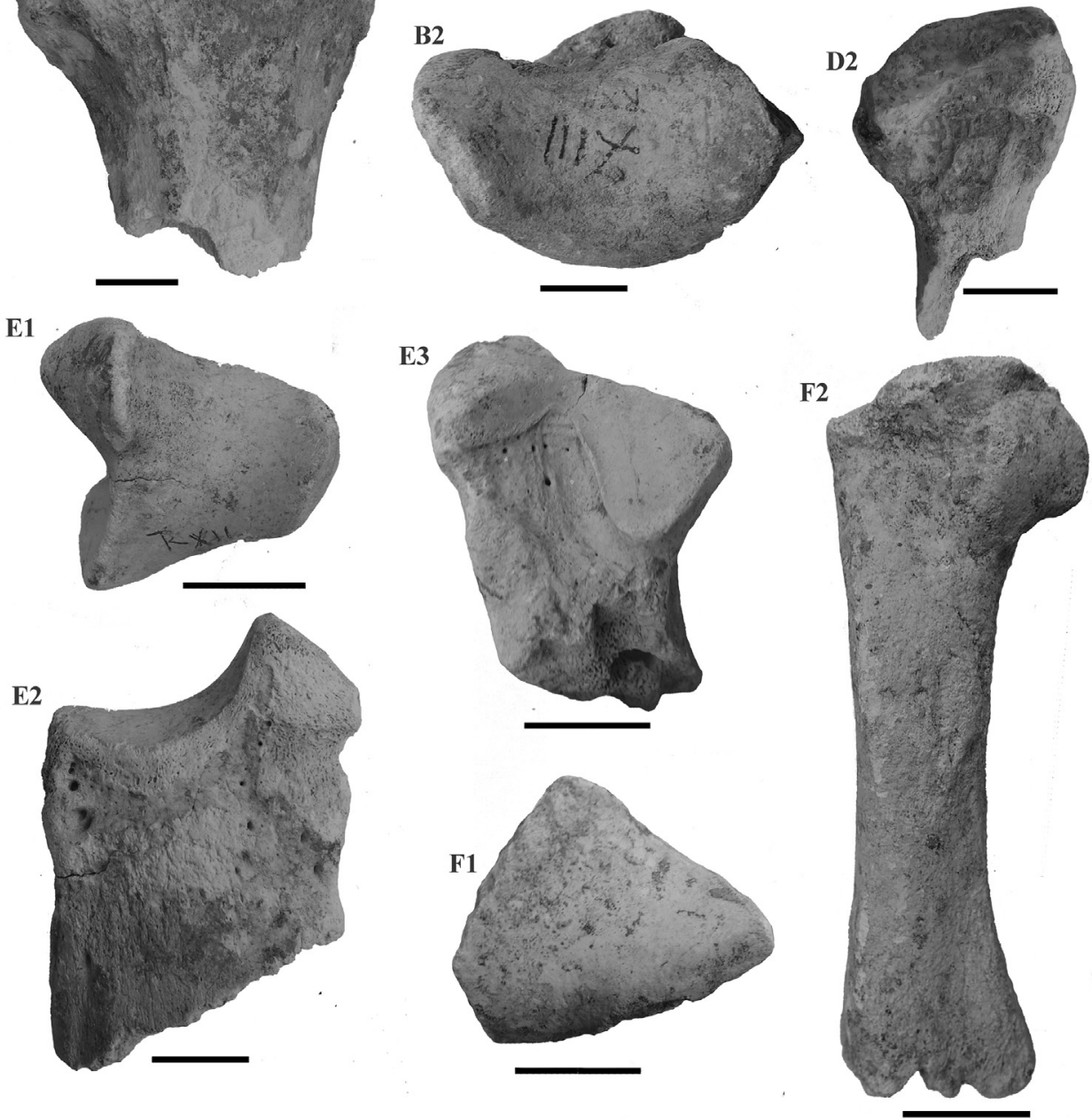

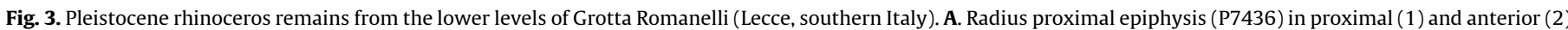

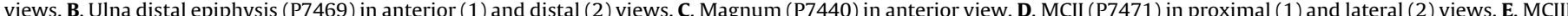
(P7456) in proximal (1), anterior (2) and lateral (3) views. F. MCIV (P7459) in proximal (1) and lateral (2) views. Scale bars: 2 cm.

Pyramidal (P7442). In dorsal view, the proximal border is convex, the medial one has a weak concavity in the middle, whereas the distal one is convex in its medial half and concave in the lateral one. A relatively large tuberosity is present in the lateropalmar portion of the bone. In medio-palmar view, two articular surfaces for the semilunar can be observed: the proximal one is elongated dorso-palmarly and is connected with the proximal articular surface of the bone; the distal one is smaller, narrow and elongated on the medial face and higher on the distal medial border of the palmar face. In S. hemitoechus the proximal articular surface on the medial face is shorter and higher than P7442; the gap between the proximal and distal articular surface on the medial face is larger than P7442. In anterior view, the anterior face is larger than P7442 and the bone appears more concave medially. In $C$. antiquitatis, the distal articular surface for the semilunar in medio-palmar view is higher than P7442 and is separated from the proximal one by a marked and deep groove. In S. kirchbergensis, the distal articular surface for the semilunar is well-developed and sub-triangular. In dorsal view, the specimen from Grotta Romanelli is proportionally higher and narrower than in S. hemitoechus, and resembles the pyramidal of $S$. hundsheimensis.

MCII (P7471). The MCII is represented only by a proximal epiphysis (Fig. 3(D)). In proximal view, the articular surface for the trapezoid is dorso-palmarly elongated and is trapezoidal in shape, 
larger in its palmar half than in the dorsal one (Fig. 3(D1)). A rounded tuberosity occurs in the palmar face of the proximal epiphysis. In lateral view, the articular surface for the magnum is long with a rather convex proximal border and a slightly concave distal border; it is separated from the proximal articular surface by a raised edge (Fig. 3(D2)). The articular surface for the third metacarpal is narrow and long and is connected with the magnum facet by a gentle edge.

The specimen differs from MCII of S. hemitoechus which has a shorter and relatively larger proximal articular surface and a less developed palmar tuberosity. For S. kirchbergensis the proximal epiphysis of MCII has a more developed palmar tuberosity, the articular surface for the third metacarpal is larger and the proximal border of the articular surface for the magnum is straight. In C. antiquitatis, the proximal articular surface is more rounded, the lateral articular surface for the third metacarpal is well developed, and the lateral articular surface for the magnum is delimited distally by a groove. In S. hundsheimensis, the proximal articular surface and the facet for MCIII are separated by a sharp edge; the articular surface for the third metacarpal is relatively long and concave in lateral view; the tuberosity is well-developed. Accordingly, the specimen P7471 from Romanelli is assigned to S. hundsheimensis.

MCIII (P7456). In dorsal view, the proximo-lateral tuberosity is prominent and the proximal articular surface for the magnum is relatively concave (Fig. 3(E2)). In proximal view the articular surface for the magnum is trapezoidal and is separated from the surface of the uncinate by a marked salience; the articular surfaces for the MCIV are observable in this view (Fig. 3(E1)). The dorsal border of the proximal epiphysis is rather straight (Fig. 3(E2)). In lateral view, the two articular surfaces for the MCIV are fused: the dorsal half of this surface is rather low and elliptical, whereas its palmar half is larger, higher, and triangular in shape (Fig. 3(E3)). In medial view, the articular surface for the second metacarpal is dorsally damaged but appears relatively well-developed.

In C. antiquitatis the palmar articular surface for the MCIV is slightly smaller than the dorsal one, the articular surface for the uncinate is well-developed and the lateral tuberosity is larger. The third metacarpal of S. kirchbergensis differs from P7456 in having a separated lateral articular surface for the MCIV, a larger dorsal articular surface for the MCIV, and a less marked salience between the proximal articular surfaces for the magnum and the uncinate. In $S$. hemitoechus, the proximal epiphysis of the third metacarpal is relatively larger than P7456; moreover, in dorsal view, the articular surface for the uncinate appears more developed than P7456, the dorsal border of the proximal epiphysis is sinuous, the lateral articular surfaces are separated, and the palmar one is less welldelineated in proximal view than in P7456. In S. hundsheimensis, in proximal view, the latero-palmar articular surface for MCIV is large, and the proximal articular surface in proximal view has a trapezoidal shape with a straight dorsal border. In lateral view, the posterior surface for the MCIV is triangular and the anterior one is small. These morphologies are similar to those observed in P7456.

MCIV (P7459). On the specimen P7459 the distal epiphysis is missing (Fig. 3(F)). In proximal view, a broad articular surface for the uncinate is present. The latter is triangular in shape, its borders are rather straight and the dorsal one has a slight concavity in the middle (Fig. 3(F1)). In medial view, the two articular surfaces for the MCIII are badly preserved; the dorsal one is small, elongated and low, whereas the palmar one is larger and circular in shape (Fig. 3(F2)). In latero-palmar view, the proximal articular surface extends over the palmar border of the proximal epiphysis, forming two elongated and narrow surfaces separated by a blunt relief.

In $S$. hemitoechus, in proximal view, the medial border is much convex, the medial palmar articular surface is usually elliptical, and the articular surfaces on the palmar face of the proximal epiphysis are more developed than P7459. Coelodonta antiquitatis differs from P7459 in having a dorsal articular surface for the third metacarpal higher and elliptical in shape, a rounded palmar articular surface and a wider diaphysis. In S. kirchbergensis, the medial side of the proximal epiphysis is higher than the lateral one; the proximal articular surface, in proximal view, is triangular in shape and extends over almost all the proximal epiphysis; the dorsal articular surface for the third metacarpal is elliptical in shape. The morphology of P7459 is close to S. hundsheimensis (see also Guérin, 1980: fig. 99A; Lacombat, 2005).

Patella (P7465). The patella is relatively small; in proximal view, it displays a less massive medial angle and a rather straight medial border. In plantar view, the medial border of the medial articular surface is slightly concave and the lateral articular surface is relatively small and less developed than the medial one. The two articular surfaces are separated by a marked relief.

The patella of S. kirchbergensis has a sub-rectangular shape in dorsal view; the proximal-lateral border is fairly straight (with less marked concavities); the proximal angle is blunt. Contrary to P7465, in S. hemitoechus the medial articular surface is large, high and with a very concave medial border in plantar view. In C. antiquitatis, the proximal-medial and distal-medial borders are concave, the medial angle is massive. In S. hundsheimensis and in P7465, the relief between the two articular surfaces is visible and developed on the distal side, suggesting an attribution of P7465 to Toula's species.

Astragalus (P7449). In dorsal view, the trochlea is relatively large; the medial and lateral lips are preserved (Fig. 4(B2)). The lateral lip is larger than the medial one. In plantar view, the proximo-lateral surface for the calcaneum is wide and concave; this surface extends distally with a smaller surface. The proximolateral surface is well separated by a marked groove from another wide, elliptical, and flat articular surface for the calcaneum which is placed in the middle of the plantar face (Fig. 4(B1)). Distally this surface is connected with an elongated third articular surface for the calcaneum. In medial view, the plantar border of the medial lip of the trochlea is regularly concave (Fig. 4(B3)). In this view, the medial tuberosity appears rounded, placed dorsally on the medial face and relatively far from the distal border of the medial face. In distal view, the dorsal border of the articular surface for the navicular is straight; the articular surface for the cuboid is short and does not extend more dorsally than that for the navicular.

In the astragalus of S. kirchbergensis, the trochlea is strongly asymmetric and the medial lip is oblique with respect to the distal border of the bone; the articular surface for the cuboid is long. In C. antiquitatis, the medial tuberosity is located palmarly on the medial face; the trochlea is elongated transversally; the dorsal border of the articular surface for the cuboid extends more dorsally than that for the navicular. The length of the articular surface for the cuboid in P7449 is smaller than in S. hemitoechus. In S. hundsheimensis, the medial face of the bone extends medially over the outline of the medial lip of the trochlea, but this character is not evident on P7449 and we cannot exclude that this feature could be related to the age of the animal. In P7449 as in S. hundsheimensis, the medial lip appears well extended and rounded in medial view, its distal border being connected with the medial face of the bone; in contrast, in S. hemitoechus the distal border does not reach the medial face. The height of the medial face is a diagnostic feature to distinguish between $S$. hundsheimensis and S. hemitoechus according to Lacombat (2006); it is smaller in $\mathrm{P} 7449(\mathrm{Hm}=70.7 \mathrm{~mm})$ than in $\mathrm{S}$. hemitoechus $(\mathrm{Hm}=\min .73 .46$, max. $84.99 \mathrm{~mm}$; Pandolfi and Tagliacozzo, 2015) and falls within the range of $S$. hundsheimensis $(\mathrm{Hm}=\min .64 .80$, $\max .76 .50 \mathrm{~mm}$; Lacombat, 2005). Accordingly, the astragalus P7449 is assigned to S. hundsheimensis. 

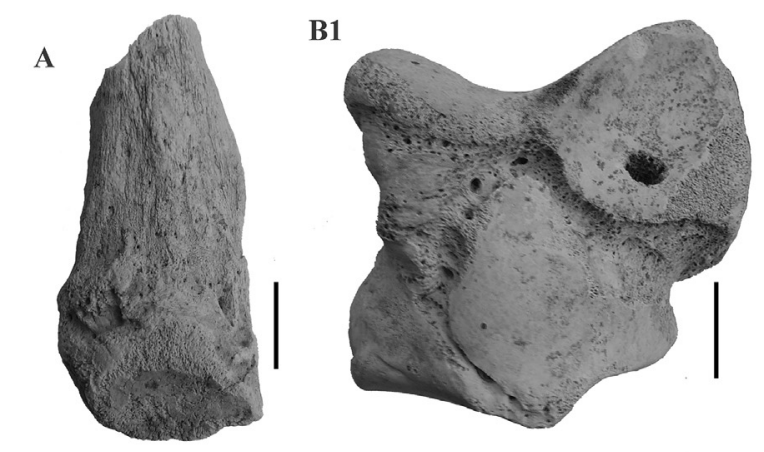

1

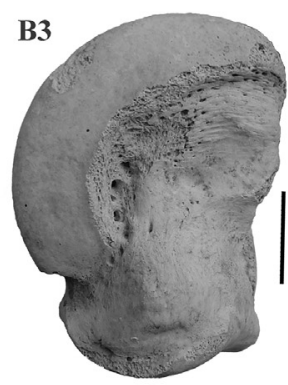

E1

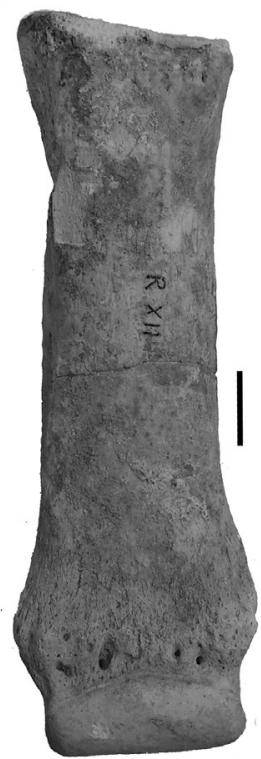

C1

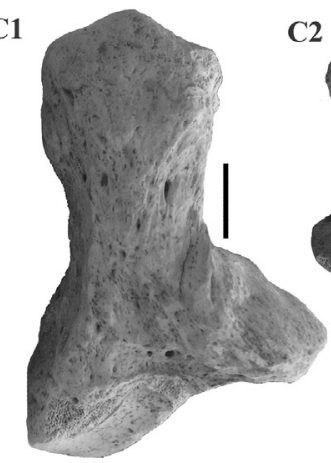

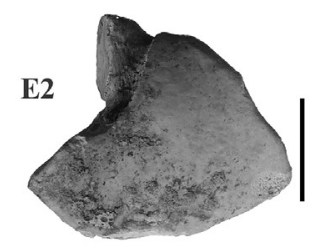

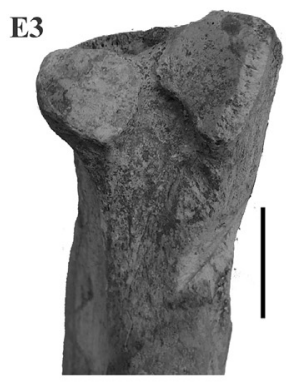

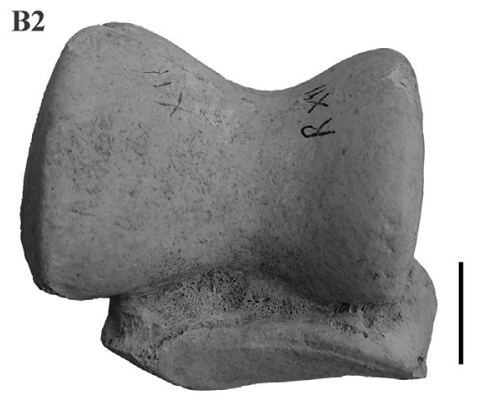

D1

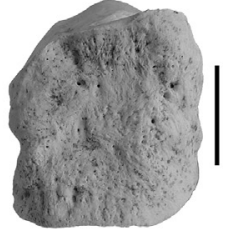

D2

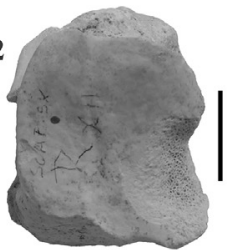

F1

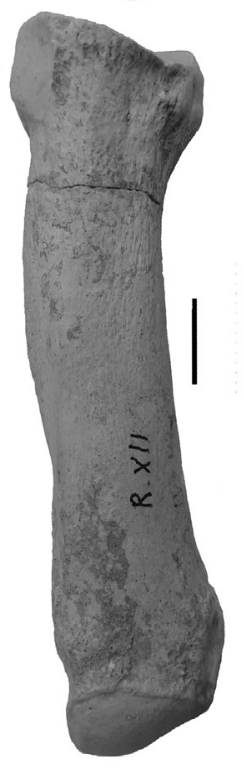

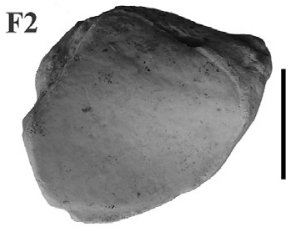

F3

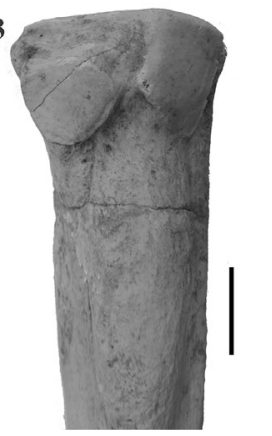

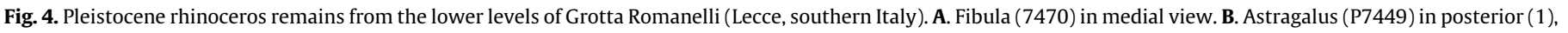

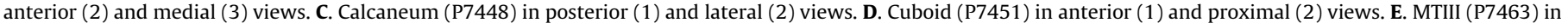
anterior (1), proximal (2) and proximo-lateral (3) views. F. MTIV (P7464) in anterior (1), proximal (2) and proximo-lateral (3) views. Scale bars: 2 cm.

Calcaneum (P7448). In lateral view, the plantar border of the bone is rather straight, convex proximally, and the beak does not protrude much beyond the tuber calcanei (Fig. 4(C2)). In dorsodistal view, three articular surfaces for the astragalus are present. The latero-proximal one is broad and sub-trapezoidal in shape; moreover, it is proximo-distally convex in the proximal half and concave in the distal one. The distal border of this surface extends distally with a small articular surface. Another articular surface is located on the sustentaculum tali; it is proximally joined with the previous one and is fused with the distal articular surface for the astragalus. The latter is elongated, relatively high and connected distally with the articular surface for the cuboid. In distal view, the articular surface for the cuboid is sub-trapezoidal in shape, its posterior and medial borders are rather straight. In plantar view, the sustentaculum tali is oblique, forming an obtuse angle with the corpus of the bone (Fig. 4(C1)).
In C. antiquitatis, the articular surface on the sustentaculum tali is sub-circular and the proximal one for the astragalus extends latero-distally; in addition, the plantar profile of the bone has a median concavity in lateral view. In S. kirchbergensis, the bone is generally larger when compared to other species of the same genus; the distal articular portion is short, the articular surface for the cuboid is sub-rectangular with a straight dorsal border, and the articular surface on the sustentaculum tali is well-joined with the distal articular surface for the astragalus. In S. hundsheimensis, the tuber calcanei generally extends beyond the beak. The position and orientation of the sustentaculum tali in plantar view is similar to that of the sustentaculum of P7448; the same is true for the morphology of the articular surface with the cuboid. This specimen is assigned to $S$. hundsheimensis.

Cuboid (P7451, P7452). Two cuboids come from Grotta Romanelli's level XII. One of them (P7451; Fig. 4(D)) is larger 
than the other (P7452); nevertheless, the two bone are similar in morphology. In dorsal view, the dorsal face is sub-trapezoidal, the lateral border is straight and higher than the medial one (Fig. 4(D1)). In proximal view, the proximal articular surface is sub-trapezoidal (Fig. 4(D2)); its lateral border is damaged whereas the medial border is slightly convex; the dorsal and plantar borders are irregular. The proximal articular surface does not reach the borders of the bone. In addition, the proximal articular surface is divided into a large lateral and a smaller medial surface by a weak groove which is more enlarged in its dorsal half. In medial view, the proximo-medial articular surface is well-delineated and connected with a long surface for the navicular. The latter surface connected with a very wide surface for the third cuneiform in the distoplantar portion of the medial face. In the same view, a small and triangular surface is present on the antero-distal side of the bone. The articular surface for the fourth metatarsal is triangular with rounded angles and slightly concave in its plantar portion. The extension of this surface is different in P7451 and P7452.

Both specimens differ from $C$. antiquitatis in which the proximal articular surface is sub-rectangular, with similar length for medial and lateral surfaces. In dorsal view, the cuboid of S. kirchbergensis has a concavity in the middle of the medial border; the medial articular surface is longer antero-posteriorly and the lateral articular surface is more developed. The specimens differ from $S$. hemitoechus by having a dorsal face higher than wide, as well as in S. hundsheimensis, with a very oblique proximal border, a slightly concave distal border (see also Guérin, 1980: fig. 105A), and a less transversally developed proximal articular surface. In addition, the articular surface for the third cuneiform in the disto-plantar portion of the medial face is wider and shorter than in S. hemitoechus. The medio-plantar border of the distal articular surface in S. hemitoechus is sinuous, while it is straight in S. hundsheimensis (Lacombat, 2005) and in P7451 and P7452. The morphological characters of these two cuboids suggest an attribution to $S$. hundsheimensis.

MTIII (P7461). In proximal view, P7461 displays a convex anterior border of the proximal epiphysis (Fig. 4(E2)); the plantar articular surface for the MTIV is partially visible. In lateral view, the dorsal articular surface is trapezoidal whereas the plantar one is rounded and smaller than the former (Fig. 4(E3)). The two surfaces are separated by a narrow groove. In medial view, the proximal epiphysis presents two articular facets; the dorsal one is slightly smaller than the plantar one, both being elliptical in shape. In this view, the plantar tuberosity on which the articular surface for MTIV is located is well delineated and large.

The dorsal border of the proximal articular surface is sinuous in S. hemitoechus; the plantar articular surface for the MTIV is slightly larger or similar in size to the dorsal one, and the articular surfaces for the MTIII are triangular in shape. In proximal view, the third metatarsal of S. kirchbergensis differs from P7461 in having a regularly convex medial border and a sinuous dorsal border, and, in lateral view, a sub-elliptical plantar articular surface for the fourth metatarsal. In $C$. antiquitatis, the two proximo-lateral articular surfaces are quite similar in size and shape; the diaphysis is wider and, in proximal view, the dorso-medial border is regularly convex. The third metatarsal from Grotta Romanelli resembles that of S. hundsheimensis in the morphology of the dorsal border of the proximal articular surface, in the development of the lateral articular surfaces, and in the morphology of the medial articular surfaces.

MTIV (P7464). In proximal view (Fig. 4(F2)), the articular surface is elongated dorso-plantarly; its dorsal border is very convex, and the plantar and medial borders are straight. Plantarly, this surface is delimited by a blunt groove. The perimeter of the proximal articular surface does not extend to the margins of the proximal epiphysis (Fig. 4(F2)). On the medial side of the bone, two articular surfaces for the third metatarsal are present. The dorsal one is square-shaped, connected with the proximal surface and slightly larger than the plantar one, which is rather rounded (Fig. 4(F3)). In lateral view, the proximal tuberosity is well delimited and the plantar side of the proximal epiphysis is higher than the dorsal one.

In $S$. hemitoechus, the proximal articular surface is delimited plantarly by a marked groove and the proximal epiphysis is larger than P7464. When compared to P7464, the fourth metatarsal of $S$. kirchbergensis displays a larger proximal articular surface which extends over almost all the proximal epiphysis, and, in dorsal view, the proximal border of the bone is rather straight. In C. antiquitatis, the bone is massive and the proximal articular surface is subtrapezoidal in shape with rounded perimetral angle. In S. hundsheimensis, as well as in P7464, the antero-medial articular surface is larger than the posterior one, and the dorsal border of the proximal articular surface is rather convex.

\section{Stephanorhinus sp.}

Referred specimens: Hemimandible (P7434), fragments of upper and lower teeth (P7476, P7477, P7484, P7485, P7486, P7487), dp4 (P7423), proximal and distal humeral epiphyses (P7445; P7474), radius (P7444), pisiform (P7443), semilunar (P7446), tibia (P7468), fibula (P7470), and MTIII (P7463).

\section{Description:}

Hemimandible (P7434). One fragmentary mandible (P7434) of a juvenile individual with $\mathrm{dp} 2-\mathrm{m} 1$ (dp1 only preserving the roots) comes from the level XII (Fig. 2). In buccal view, the horizontal ramus is relatively high and the ventral profile is convex. Three mental foramina are present: the largest one is located below the mesial half of dp2 (Fig. 2(A)). The dorsal border of the preserved area of the vertical ramus is bent backward. In lingual view, the $\mathrm{m} 2$ (Fig. 2 (B, C)) is erupting. In dorsal view, the aboral border of the symphysis is located between $\mathrm{dp} 1$ and $\mathrm{dp} 2$. Two roots of $\mathrm{dp} 1$ can be observed. dp2 has a lingually-closed posterior valley, an anterior groove on the ectolophid and a simple paralophid. dp2 and dp3 display an ectolophid fold. On dp3, the paralophid is double and a small protoconid fold is present. Lingual valleys on dp3, dp4 and $\mathrm{m} 1$ have $\mathrm{V}$-shaped morphology. The difference in height between the bottoms of the valleys is strong on $\mathrm{m} 1$ as well as on dp3 and dp4.

The positions of the mental foramen and the posterior border of the symphysis do not seem to be good discriminant characters to give a clear taxonomic attribution for young individuals as they are almost similar for S. kirchbergensis, S. hundsheimensis, and S. hemitoechus (Kahlke, 1977, 2001; Koenigswald et al., 2007).

Dentally, S. hemitoechus often bears deciduous teeth with Vshaped lingual valleys (Guérin, 1980; Lacombat, 2005) and the same occurs also in S. hundsheimensis. In S. kirchbergensis, the posterior valley is opened lingually on dp2; dp2s, dp3s and dp4s have U-shaped valleys. Similar morphologies have been reported by Guérin (1980) and they also occur in several specimens from Taubach figured by Kahlke (1977). In addition, Guérin (1980) reported dp2s with a small V-shaped anterior lingual valley. According to Lacombat (2005) the difference in height between the bottoms of the valleys on $\mathrm{dp} 3$ of $S$. hundsheimensis is reduced whereas it is marked in $S$. kirchbergensis and variable in S. hemitoechus. However, this difference is small on the dp3s of S. kirchbergensis from Taubach. The $\mathrm{dp} 2$ of $S$. hundsheimensis from Mosbach has a posterior valley opened lingually and the same occurs in those from Untermassfeld.

Diagnostic morphological characters of juvenile Pleistocene rhinoceroses need to be further investigated. Hence, the specimen from Grotta Romanelli is provisionally assigned to Stephanorhinus sp.

Tooth fragments. Several upper and lower tooth fragments (P7476, P7477, P7484, P7485, P7486, P7487) come from level XII of 
Grotta Romanelli. They are too small and badly preserved to yield diagnostic morphological characters. The enamel is rough, suggesting the teeth cannot be referred to S. kirchbergensis, and it is less thick and developed than in $C$. antiquitatis. The specimens are provisionally assigned to Stephanorhinus sp.

dp4 (P7423). A small lower deciduous tooth comes from the level XII of Grotta Romanelli. The tooth is characterised by a Ushaped anterior lingual valley and a V-shaped posterior lingual valley. Cingula are absent, the trigonid is rounded, the ectolophid groove is marked and stretched to the neck. The bottoms of the valleys are located at very different heights.

U-shaped anterior valleys have been reported by Lacombat (2005) only for S. kirchbergensis. However, the sample considered by this author consists only of two fourth deciduous teeth. Guérin (1980) observed a larger sample and reported V- and U-shaped anterior lingual valleys for both $S$. hemitoechus and S. kirchbergensis. A strong difference in height between the bottoms of the lingual valleys has been reported in S. kirchbergensis by Guérin (1980) and Lacombat (2005). Stephanorhinus hundsheimensis has $\mathrm{U}$ - or large $\mathrm{V}$-shaped posterior lingual valleys according to Guérin (1980), whereas it has V- or large Vshaped valleys according to Lacombat (2005). The difference in height between the bottoms of the valleys can be strong in S. hundsheimensis (Lacombat, 2005).

Concerning the measurements, the maximal length is shorter compared to other Pleistocene species whereas the maximal width is close to the minimal values of $S$. hemitoechus and $S$. kirchbergensis. The height of the unworn crown falls within the range of $S$. hemitoechus and $S$. hundsheimensis. The specimen is here referred to Stephanorhinus sp.

Humerus (P7445, P7474). Two humeral fragments have been identified; they could belong to the same specimen. A fragment of proximal epiphysis (P7445) is too badly preserved to be described; only the distal fragment (P7474) presents some diagnostic characters. In cranial view, the lateral border of the lateral lip of the distal trochlea is slightly convex. The trochlear trough is wide; the lateral tuberosity is poorly developed in this view. In distal view, the lateral tuberosity is prominent and rounded, the lateral epicondyle is not very developed. A subadult individual of $S$. hemitoechus from Valle Radice in which the proximal epiphysis is not completely fused differs from the Grotta Romanelli specimen in having a well-developed lateral distal tuberosity, prominent in cranial view, and a sinuous lateral border of the lateral lip of the trochlea. These characters are shown also by adult individuals and they can be considered as valid for species discrimination. Unfortunately, juvenile humeri of $S$. hundsheimensis and S. kirchbergensis have not been observed so far. An attribution to $S$. hemitoechus is excluded; hence, the remain is provisionally referred to as Stephanorhinus sp.

Radius (P7444). A juvenile radius lacking the distal epiphysis is observed. The proximal epiphysis is relatively large; in proximal view, the dorsal border of the epiphysis is rather straight in its lateral half and slightly convex in its medial half. The angle between the palmar borders of the two proximal articular surfaces is obtuse. The lateral articular surface is square-shaped and smaller than the medial one. The lateral and medial surfaces are separated by a saddle which is curved towards the lateral margin in its dorsal half. In dorsal view, the coronoid process is prominent. In palmar view, two articular surfaces for the ulna are well-developed.

This radius differs from the specimen P7436 in the morphology and development of the proximal lateral articular surface and in the morphology of the dorsal border of the epiphysis. Nevertheless, these differences could be related to the age of the animal. Unfortunately, a detailed study of juvenile remains of Pleistocene rhinoceroses has not yet been performed; the specimen P7444 is provisionally referred to Stephanorhinus sp.
Pisiform (P7443). In proximal view, the articular surface for the radius is triangular and the lateral border of the bone is concave. In lateral view, the palmar tuberosity is larger in P7443 than in S. hemitoechus from Valle Radice (Pandolfi and Tagliacozzo, 2015). The bone is shorter and larger than in S. hemitoechus; the latter species also displays, in dorsal view, an articular surface for the pyramidal larger than in P7443. The studied specimen is provisionally assigned to Stephanorhinus sp.

Semilunar (P7446). The bone is dorsally damaged. In proximal view, the proximal articular surface is convex in its dorsal half and concave in the palmar one. The articular surface for the scaphoid is imperfectly delineated in proximal view; it is elongated, rather flat, and longer than the articular surface for the radius-ulna. In distal view, a marked crest separated the elongated magnum facet with rather straight lateral borders from the concave uncinate facet. Unfortunately, the diagnostic features of this bone are represented by the morphology of the dorsal face and of the dorso-proximal articular surface which lack or are damaged in the specimen from Grotta Romanelli. Therefore, P7446 is provisionally referred to as Stephanorhinus sp.

Tibia (P7468). The tibia belongs to a young individual, with epiphyses missing because they are unfused or destructed. Any morphological comparison is prevented and the specimen is referred as Stephanorhinus sp. The specimen appears slenderer than a juvenile tibia of Coelodonta.

Fibula (P7470). A distal epiphysis of fibula figures in the collection of bones from Grotta Romanelli (Fig. 4(A)). The distal articular surface is elliptical and less developed transversally than the epiphysis. The only possible remark on this specimen is that it is smaller (DTD $=38.5 \mathrm{~mm}$ ) than the fibula of $S$. hemitoechus from Arago (DTD = min. 44.49 mm, max. 52.04 mm; Lacombat, 2005). The specimen is determinate as Stephanorhinus sp.

MTIII (P7463). P7463 preserves only the distal epiphysis and part of the diaphysis and cannot be morphologically compared in details.

Remarks: Several small and badly preserved fragments of postcranial remains and some phalanges are also determined (Table 1). The preservation of the fragmented bones and the absence of useful morphological characters to distinguish the Pleistocene rhinoceroses species, did not allow a taxonomic attribution; this material is referred to Stephanorhinus sp.

\section{Results}

\subsection{Taphonomic analysis}

The rhinoceros specimens studied here include various elements of the skeleton and a few teeth; remains of the autopode of the anterior and posterior limbs are well-represented, including carpal bones (Number of Remains $=5)$, tarsal bones $(N R=4)$, phalanges $(\mathrm{NR}=10)$, and metapodial bones $(\mathrm{NR}=10)$. Anterior and posterior limb bones are almost represented by the equivalent number of specimens; only several phalanges cannot be referred specifically to any one of the limbs (Table 2).

Only postcranial remains come from level XI $(N R=7)$. The remains can be referred to at least two individuals: a juvenile (ulna and an unfused distal epiphysis of metacarpal) and an adult (scapula, distal epiphysis of femur, patella, calcaneum, and MTIV). Many more remains of rhinoceros come from level XII: fragments of vertebrae and costae of a large size mammal, alongside phalanges, probably belonging to the posterior limbs.

The MNI suggests the presence of at least five individuals: a calf (unworn deciduous tooth), a young individual (mandible with erupting $\mathrm{m} 1$ and several bones with unfused epiphyses), and three adults (metapodial bones and phalanges with completely fused 
Table 4

Isotopic values measured for the sampled Pleistocene rhinoceros specimens from Grotta Romanelli (Lecce, southern Italy).

\begin{tabular}{|c|c|c|c|c|c|}
\hline Stratigraphic level & Inventory number & $\delta^{13} \mathrm{C}(\% . \mathrm{V}-\mathrm{PDB})$ & $\delta^{18} \mathrm{O}_{\mathrm{CO} 3}(\% . \mathrm{V}-\mathrm{SMOW})$ & $\delta^{18} \mathrm{O}_{\mathrm{PO} 4}(\% . \mathrm{V}-\mathrm{SMOW})$ & $\delta^{18} \mathrm{O}_{\mathrm{CO} 3}-\delta^{18} \mathrm{O}_{\mathrm{PO} 4}$ difference (\%o) \\
\hline IX & P7475 & -13.0 & 27.7 & 20.6 & 7.2 \\
\hline IX & P7481 & -12.9 & 26.3 & 17.9 & 8.4 \\
\hline IX & P7482 & -13.1 & 26.8 & 17.5 & 9.3 \\
\hline IX & P7483 & -12.7 & 26.7 & 17.9 & 8.8 \\
\hline$X$ & P7478 & -11.9 & 27.7 & 20.1 & 7.5 \\
\hline$X$ & P7479 & -12.2 & 26.6 & 19.2 & 7.4 \\
\hline$X$ & P7480 & -11.8 & 26.8 & 18.8 & 8.0 \\
\hline XII & P7476 & -12.2 & 27.5 & 19.8 & 7.6 \\
\hline XII & P7477 & -12.1 & 26.4 & 18.9 & 7.5 \\
\hline XII & P7484 & -12.3 & 27.1 & 20.1 & 7.0 \\
\hline XII & P7485 & -12.2 & 26.6 & 18.9 & 7.7 \\
\hline XII & P7486 & -12.4 & 25.7 & 18.5 & 7.2 \\
\hline
\end{tabular}

epiphysis). Unfortunately, some remains are abraded and covered by sediment which prevent any kind of analyses of the cortical surface of the bones.

Four different degrees of preservation are represented: (1) wellpreserved, brown, without crust bones; (2) white bones with abraded surfaces; (3) grey bones covered by sediment, in particular small gravels; and (4) reddish bones covered by red concretions. These four degrees have been recorded from both levels XI and XII, suggesting the presence of several depositional layers. Juvenile remains (mandible, radius, ulna, humerus, MCIV) from level XII are characterized by the preservation type 3 , whereas several short bones are characterized by degrees 1 and 3. Evidence of human and carnivore activity have not been observed on the studied remains. Traces of combustion are recorded on 6 bones from level XII. A partial blackish-brown combustion (stage 2 in Stiner et al., 1995) is present on the magnum, on the pyramidal and on the first phalanx of the fourth digits. A blackish combustion (stage 3 in Stiner et al., 1995 ) is present on the phalanges belonging to the same central digit $\left(1^{\circ}-3^{\circ}\right.$ phalanx). These remains are well-preserved and do not display concretions; maybe they were burned before being disarticulated. There is no evidence that the remains were burned by humans; it could correspond to natural fire, even if it seems difficult to consider this possibility in a cave.

\subsection{Stable isotope analyses}

The samples have $\delta^{18} \mathrm{O}_{\mathrm{CO} 3}-\delta^{18} \mathrm{O}_{\mathrm{PO} 4}$ offsets between $7.0 \%$ and 9.3\% (Tables 4 and 5), which are within the range of natural variability and do not indicate diagenetic alteration (Martin et al., 2008; Pellegrini et al., 2011). The average $\delta^{13} C_{\mathrm{CO} 3}$ values for the three different stratigraphic levels are $-12.9 \pm 0.2 \%$ for level IX, $-12 \pm 0.2 \%$ for level X, and $-12.2 \pm 0.1 \%$ for level XII. Although a two tailed $t$-test indicate significant differences between level IX and $X(p=0.002)$, a non-parametric Mann-Whitney test suggests that the difference is not significant $(\mathrm{p}=0.052)$ at the $\mathrm{p}<0.05$ significance level. The average $\delta^{13} C_{\text {diet, meq }}$ values for the different stratigraphic levels range from $-26.6 \%$ to $-27.6 \%$.

The average $\delta^{18} \mathrm{O}_{\mathrm{PO} 4}$ values range from $18.5 \pm 1.4 \%$ to $19.4 \pm 0.7 \%$, with no significant differences between the stratigraphic levels. Combining the results of the two different equations by Kohn and Cerling (2002) and Amiot et al. (2004), the calculated environmental water values are $-5.5 \pm 2 \%$ for level IX, $-4.5 \pm 1.2 \%$ for level X, and $-4.4 \pm 1.2 \%$ for level XII.

\subsection{Volcanic ash in level XII}

The level XII is rich in light yellow coarse ash. In thin section the ash shows a glassy and vesicular texture containing scarce phenocrysts (Fig. 5). The glass is brownish in color, almost totally transformed in secondary minerals and contains abundant (70-
$80 \%_{\text {vol }}$; volume percent) subrounded vesicles (Fig. 5(A)). Olivine, which is the most abundant phenocryst $(1 \%$ vol $)$, is millimeter- to sub-millimeter-sized, euhedral to anhedral, and forms crystal clots (Fig. 5(A)). Clinopyroxene and plagioclase $(<1 \%$ vol $)$ are subhedral, millimeter- to sub-millimeter- sized. The mineralogical assemblage includes olivine, clinopyroxene and plagioclase, which indicate that the ash in the level XII has a mafic composition. The quantitative chemical analyses of the mineralogical phases obtained by the electron microprobe show a content of $80 \%$ wt (weight percent) of forsteritic molecule in the olivine, a diopsidic composition for the clinopyroxene, and a Ca-rich composition for the plagioclase. These chemical data confirm that the volcanic ash contained in the level XII of Grotta Romanelli was originated from a mafic magma. A similar indication was obtained from rare and small zones of less altered glass which were found by means of scanning electron microscope (SEM) observations. Actually, the semi-quantitative energy dispersive system analyses of these glass zones performed at the SEM shows relatively high content of MgO (up to $\sim 3 \%_{\text {wt }}$ ).

\section{Discussion}

\subsection{Biochronology}

The fossiliferous levels XII and XI of Grotta Romanelli have been assigned to the late Pleistocene (Bologna et al., 1994). Neverthe-

Table 5

Isotopic average values, MAP (Mean Annual Precipitation, in mm) and MAT (Mean Annual Temperature, in ${ }^{\circ} \mathrm{C}$ ) calculated for the sampled Pleistocene rhinoceros specimens from Grotta Romanelli (Lecce, southern Italy).

\begin{tabular}{|c|c|c|c|}
\hline & Level IX & Level XI & Level XII \\
\hline \multicolumn{4}{|l|}{$\delta^{13} \mathrm{C}$ results } \\
\hline Average $\delta^{13} \mathrm{C}$ values (\%, VPDB) & -12.9 & -12.0 & -12.2 \\
\hline Standard deviation & 0.15 & 0.18 & 0.11 \\
\hline$\delta 13 C_{\text {diet meq (\%) }}$ & -27.6 & -26.6 & -26.9 \\
\hline Calculated MAP (Kohn, 2010) & $460 \pm 230$ & $220 \pm 110$ & $280 \pm 140$ \\
\hline \multicolumn{4}{|l|}{$\delta^{18} 0$ results } \\
\hline Average $\delta^{18} \mathrm{O}$ values (\%, VSMOW) & 18.5 & 19.4 & 19.4 \\
\hline Standard deviation & 1.39 & 0.70 & 0.71 \\
\hline $\begin{array}{l}\text { Environmental water } 1 \\
\quad(\%, \text { Kohn and Cerling, 2002) }\end{array}$ & -5.0 & -4.0 & -4.0 \\
\hline $\begin{array}{l}\text { Environmental water } 2 \\
\quad(\%, \text { Amiot, 2004) }\end{array}$ & -5.9 & -4.9 & -4.8 \\
\hline $\begin{array}{l}\text { MAT }\left({ }^{\circ} \mathrm{C}\right) \text { based on calculated water } 1 \\
\quad \text { (Skrzypek, 2016, Italy) }\end{array}$ & 15.5 & 17.0 & 17.1 \\
\hline $\begin{array}{l}\text { MAT }\left({ }^{\circ} \mathrm{C}\right) \text { based on calcualted water } 2 \\
\quad \text { (Skrzypek, 2016, Italy) }\end{array}$ & 14.1 & 15.7 & 15.7 \\
\hline $\begin{array}{l}\text { MAT }\left({ }^{\circ} \mathrm{C}\right) \text { based on calculated water } 1 \\
\quad \text { (Pryor, 2014, Europe) }\end{array}$ & 16.4 & 18.3 & 18.4 \\
\hline $\begin{array}{l}\text { MAT }\left({ }^{\circ} \mathrm{C}\right) \text { based on calculated water } 2 \\
\quad \text { (Pryor, 2014, Europe) }\end{array}$ & 14.8 & 16.7 & 16.8 \\
\hline MAT $\left({ }^{\circ} \mathrm{C}\right)$ combined results & $15.5 \pm 3.9$ & $17.1 \pm 2.7$ & $17.2 \pm 2.7$ \\
\hline
\end{tabular}



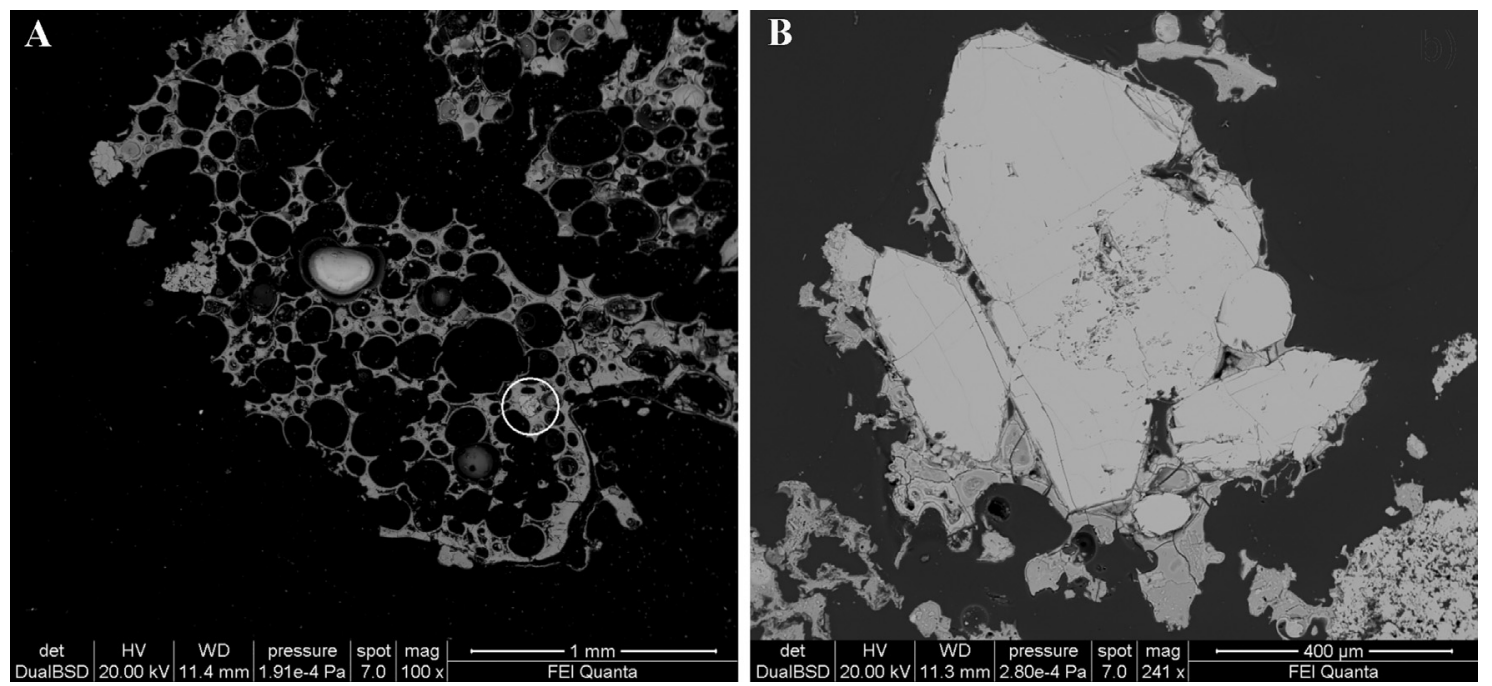

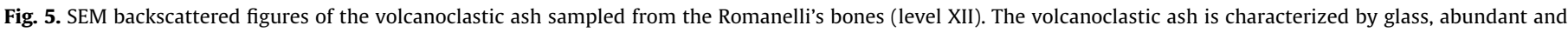

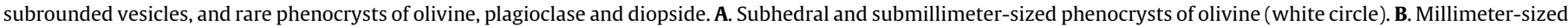
crystal clots of olivine.

less, the mammal remains collected from these levels have not been recently revised. Most of the papers published on Grotta Romanelli aimed at investigating and revising the abundant material collected from the so-called "Terre rosse" level G, chronologically referred to MIS 3 (late Pleistocene), or "Terre brune" level E, chronologically referred to the Holocene time period (Fig. 1). Unfortunately, the lower levels of the cave were completely excavated during the past century and direct stratigraphical observations are no more possible.

A short revision on hippopotamus remains from levels XII and X (H-K in Blanc, 1953, who referred all the specimens to H. amphibius) has been reported by Mazza (1995) which recorded the presence of the early and middle Pleistocene $H$. antiquus and H. tiberinus (= Hippopotamus antiquus according to Petronio, 1995), thus suggesting that the lowest deposits of Grotta Romanelli should be dated to the first half of the middle Pleistocene, in agreement with Coltorti et al. (1980) and Sala (1980). The presence of $H$. antiquus (or closely related forms also classified as $H$. tiberinus or H. ex gr. H. antiquus; see discussion in Caloi et al., 1980; Petronio, 1986; Petronio, 1986, 1995; Mazza, 1995; Athanassiou and Bouzas, 2010) suggests an age referable to the first half of the middle Pleistocene. Indeed, $H$. antiquus was surely present in Italy until MIS 15. During this time, the species occurred at Maglianella (Rome; Caloi et al., 1980; Petronio, 1986, 1995; Marra et al., 2014) and at Via Portuense (Rome; Marra et al., 2014), whereas the occurrence of $H$. amphibius in Italy was chronologically related to MIS 13 or MIS 11 (Pandolfi and Petronio, 2015).

The presence of Stephanorhinus hundsheimensis, identified in this work, also suggests a middle Pleistocene age for levels XII and XI of Grotta Romanelli, in agreement with the conclusion reported by Mazza (1995). This species is recorded in Europe during the latest early and middle Pleistocene in several sites such as Vallonnet, Untermassfeld, Soleilhac, Mosbach, Isernia La Pineta, and Mauer (Guérin, 1980; Fortelius et al., 1993; Kahlke, 2001; Schreiber 2005; Lacombat, 2005; Pandolfi and Erten, 2017). According to Pandolfi and Petronio (2011a, b), the first occurrence of the species in Italy was during the early Galerian at Cava Redicicoli (North of Rome). Nevertheless, the chronological attribution of the mammalian fauna discovered by Blanc (1955) in the latter locality has been debated (Di Stefano et al., 1998; Palombo et al., 2004; Milli and Palombo, 2005), and Cava Redicicoli was recently dated to the early-middle Pleistocene transition (Marra et al., 2014). However, some rhinoceros remains collected from the Leffe Basin (Vialli, 1956) display morphological characters which suggest an attribution to S. hundsheimensis (Pandolfi and Erten, 2017). An adult individual ("individual B" in Vialli, 1956) has been collected from a lignite bed chronologically close to the beginning of the Jaramillo subchron (level 5 in Vialli, $1956=$ unit 7 of Ravazzi et al., 2009; Pandolfi and Erten, 2017;Fig. 6). Toula's species disappeared from the Italian Peninsula during the MIS 1516 and was replaced by S. hemitoechus (Pandolfi et al., 2013; Pandolfi and Marra, 2015;Fig. 6). The earliest occurrence of S. hemitoechus in Italy has been reported by Pandolfi et al. (2013) from the Campagna Romana, approximately at $0.5 \mathrm{Ma}$ (Fig. 6); the species was very common in several late middle and late Pleistocene Italian localities (Guérin, 1980; Pandolfi et al., 2013). In the Apulian area, remains of large $S$. hundsheimensis have been reported from the early middle Pleistocene karst filling of Contrada Monticelli (Castellana, Bari) by Mazza and Varola (1999). In this locality, S. hundsheimensis has been recovered together with a small-sized etruscan-like rhino which was considered most likely a reworked element (Mazza and Varola, 1999) as well as badly preserved remains of elephants (Palaeoloxodon antiquus), equids (Equus caballus), cervids (Cervus elaphus and Dama dama), bovids (Bos vel Bison), and canids (Canis mosbachensis; Mazza and Varola, 1999; the canid was recently revised by Mecozzi et al., 2017). The specimens identified as S. cf. hundsheimensis by Mazza et al. (1993) from the early Pleistocene Apulian locality of Pirro Nord (Apricena, Foggia) have been recently re-attributed to Stephanorhinus etruscus in several papers (van der Made, 2010; Pandolfi and Petronio, 2011b; Pandolfi et al., 2013, 2015, 2017a, b).

Other mammal remains belonging to the faunal assemblage of the lower levels of Grotta Romanelli are relatively scarce and badly preserved; some cannot be identified at the species or genus level. According to Blanc (1920), the level K (XII) includes Rhinoceros merckii (= Stephanorhinus hundsheimensis and Stephanorhinus sp. in this work), Hippopotamus amphibius $(=H$. antiquus after Mazza, 1995), Dama dama and Oryctolagus cuniculus. A preliminary revision of the mammal assemblage collected in level $\mathrm{K}$ revealed that the fallow deer is represented by scant postcranial material whose bad state of preservation prevents us from any certain attribution to the late middle and late Pleistocene D. dama (sensu Di Stefano and Petronio, 1997). The material referred to O. cuniculus has been never revised in recent papers; the species seems to occur in Italy for the first time during the Torre in Pietra FU, late middle Pleistocene, MIS 10-9, whereas the species O. burgi (Kotsakis et al., 


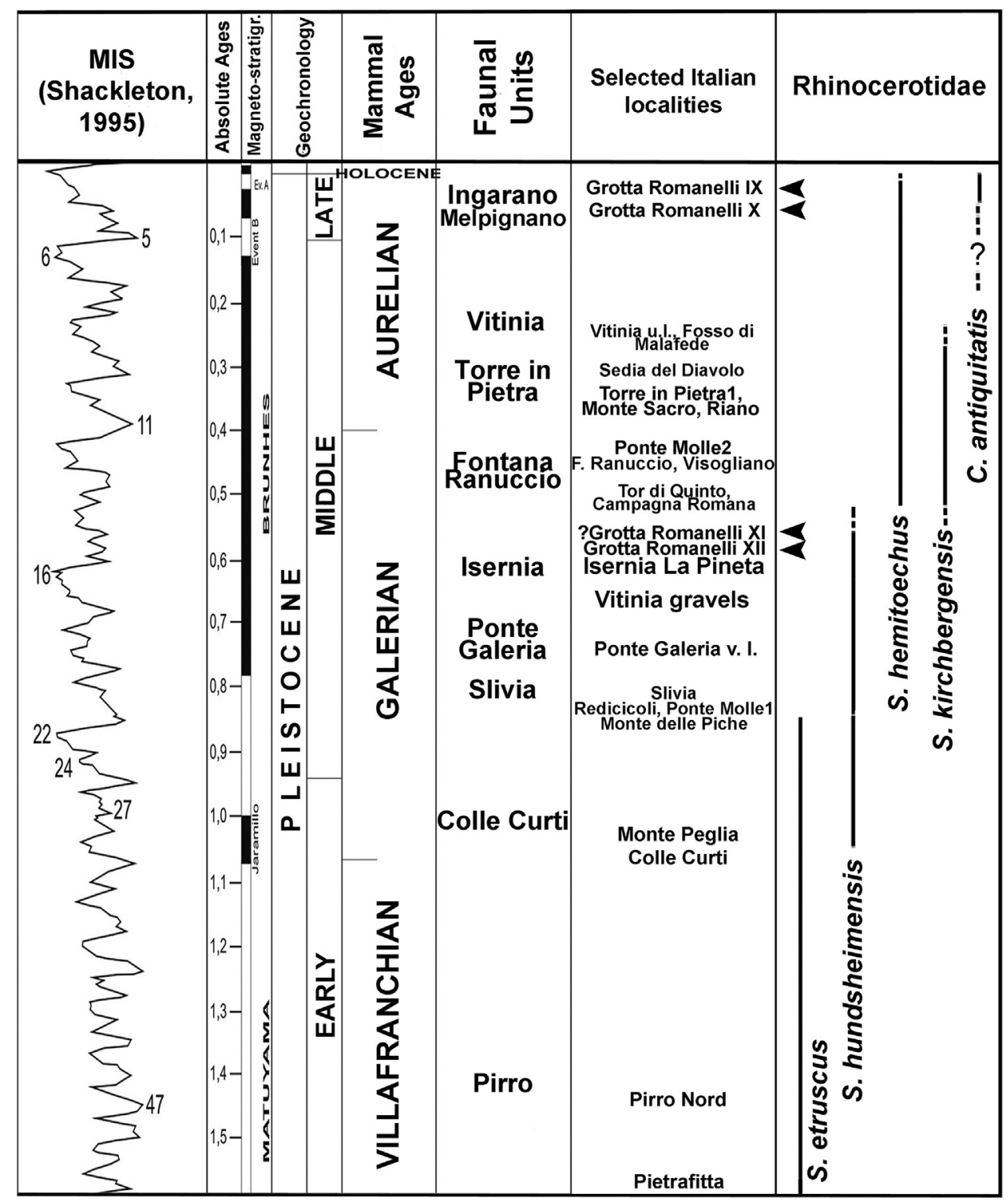

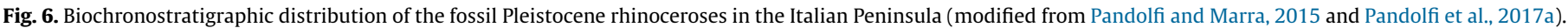
The new suggested chronological position of the levels IX, X, XI and XII of Grotta Romanelli is indicated by the black arrows.

2003) occurred during the early middle Pleistocene. Nevertheless, the few fragmented remains attributable to lagomorphs do not display diagnostic features useful to distinguish among the different species.

According to Blanc (1920), the level I (XI) yielded remains of Elephas sp. (= recte Palaeoloxodon), Rhinoceros merckii (= S. hundsheimensis and Stephanorhinus sp. in this work), Hippopotamus amphibius ( $=$ H. antiquus after Mazza, 1995), Bos taurus var. primigenius, Cervus elaphus var. corsicanus, Dama dama, Capreolus capreolus, Equus caballus (= recte Equus ferus), Canis aureus?, Sus scrofa ferus (= recte Sus scrofa), Corvus corax, Columba livia, Aquila sp., Lycos monedula, Turdus sp., and Bufo vulgaris. Neither the fallow nor the red deer can be identified at the subspecific level due to the absence of antlers and to the bad state of few fragmental post-cranial remains. Bos primigenius (= Bos taurus var. primigenius in Blanc, 1920) is represented at Grotta Romanelli by some postcranial remains; this species occurred early in Italy at Venosa-Notarchirico, ca. $600 \mathrm{ka}$ (Cassoli et al., 1999; Lefèvre et al., 2010), accompanied by Bison schoetensacki. The aurochs have been recorded in fossiliferous localities of the Roman area geochronologically dated to $\mathrm{ca}$. $500 \mathrm{ka}$ (Valle Giulia Fm.,
MIS 13; Marra et al., 2014). Scantly remains (a very few isolated teeth) of a small-sized canid (Canis mosbachensis?) have also been collected from level XI; they have never been subjected to morphological verification, as for the supposed remains of O. cuniculus. Other taxa (i.e., Palaeoloxodon sp., S. scrofa, C. capreolus, and E. ferus) have no restricted time spans (Petronio et al., 2011). The presence of S. hundsheimensis, H. antiquus, and probably C. mosbachensis indicate that also level I (XI) can confidently be dated to the middle Pleistocene. The occurrence of the aurochs suggests an age around or younger than $600 \mathrm{ka}$.

Hence, based on these biochronological conclusions, the levels XII (K) and XI (I) of Grotta Romanelli can reasonably be assigned an age spanning from MIS 15 to MIS 13 (Isernia Faunal Unit sensu Petronio et al., 2011 and Marra et al., 2014).

\subsection{Age of the volcanoclastic ash}

A middle Pleistocene age is also consistent with the presence of the volcanoclastic material. Texture and composition indicate that the volcanic ash in the level XII was originated from a mafic explosive eruption. These eruptions usually originate from 
monogenic hydromagmatic centers whose products have limited areal distribution (e.g., Sottili et al., 2012). The absence of this type of eruptive center close to Grotta Romanelli suggests a far and different origin for the volcanic ash in the level XII. The high amount of vesicles in the ash fragment indicates, indeed, an efficient process of volatile exsolution which is typical of explosive magmatic eruption (Palladino et al., 2014). The occurrence of centimeter-sized pumices in association with the analysed ash (Lazzari, 1955) supports a Plinian eruptive style at the origin of the volcanic material which was successively transported to the Grotta Romanelli by the sea waves.

Mafic Plinian eruptions are relatively rare (Freda et al., 2011). Nevertheless, the Monte Vulture, which is the closest Pleistocene volcanic district to the Grotta Romanelli, is relatively rich in mafic explosive products. In particular, the olivine-bearing texture of the ash (Fig. 5) and the chemical composition of the pumices reported by Lazzari (1955) link the volcanic material accumulated in Grotta Romanelli to the first phase of Vulture's activity (Giannandrea et al., 2006). Olivine is abundant in some pyroclastic layers of the Rionero subsynthem $(630 \pm 20-714 \pm 18 \mathrm{ka}$; Villa and Buettner, 2009), whose tephra fall deposits can be found in distal outcrops (e.g., Atella Basin, Venosa Basin, and Fossa Bradanica) with thicknesses up to $30-40 \mathrm{~cm}$ and with centimeter-sized pumice (Giannandrea et al., 2006).

\subsection{Palaeoenvironment as inferred by isotope analysis}

The presence of levels of different age at Grotta Romanelli is also confirmed by the results of the isotope analyses performed for this study. Levels XII and X show the same isotopic values and differ from those obtained from level IX, which suggests that the former two levels were deposited under different climatic conditions than the latter one. The average $\delta^{13} C_{\text {diet, meq }}$ values for the different stratigraphic levels range from $-26.6 \%$ to $-27.6 \%$. These values indicate pure $C_{3}$ feeding and are halfway within the range of $C_{3}$ vegetation. Values lower than $-30 \%$ would indicate closed canopy forest, whereas values higher than $-25 \%$ would suggest water stressed vegetation. If it is assumed that the diet of the animals is representative of the average vegetation of the area, the calculated values fit Domingo et al.'s (2013) category of woodland-mesic grassland. Differences in the $\delta^{13} \mathrm{C}$ values may indicate different vegetation, amount of precipitation and/or humidity. The lower value in level IX (which is referred to the first half of MIS 3) indicates denser vegetation and/or higher precipitation than when level $\mathrm{X}$ and XII deposited. Assuming that changes in $\delta^{13} \mathrm{C}$ values reflect varying precipitation and trivial changes in the vegetation, the mean annual precipitation (MAP) would be estimated using Kohn's (2010) equation. However, the uncertainty of this equation is high ( $\mathrm{ca} .50 \%$ of the calculated MAP). Using this equation, MAP values are $460 \pm 230 \mathrm{~mm} /$ year for level IX, and $220 \pm 110 \mathrm{~mm} /$ year and $280 \pm 140 \mathrm{~mm} /$ year in levels X and XII, respectively (an altitude of $0 \mathrm{~m}$ a.s.l. and a latitude of $40^{\circ}$ were used in the equation; little changes in altitude and latitude have negligible effects on the equation). Recent MAP values in the area give a range of 440$680 \mathrm{~mm} /$ year (Combourieu-Nebout et al., 2015). This could mean that the climate in level IX likely was as humid as today whereas levels X and XII could have been more arid. However, the absence of pollen record does not allow for reconstructing the palaeoenvironment more precisely.

$\delta^{18} \mathrm{O}_{\mathrm{w}}$ values usually correlate strongly with $\delta^{18} \mathrm{O}$ values of the local precipitation $\left(\delta^{18} \mathrm{O}_{\mathrm{ppt}}\right) \cdot \delta^{18} \mathrm{O}_{\mathrm{ppt}}$ values are controlled by several factors. Generally, the mean annual temperature (MAT) has the greatest effect on it, and can be estimated based on $\delta^{18} \mathrm{O}_{\mathrm{ppt}}$ values (Dansgaard, 1964; Rozanski et al., 1993). Other factors like the different source of moisture, air mass trajectories, latitude, and altitude have also an influence on $\delta^{18} \mathrm{O}_{\mathrm{ppt}}$ values. In the Apulian area, the closeness of the Adriatic and Ionian seas heavily bias $\delta^{18} \mathrm{O}_{\mathrm{ppt}}$ values. Because the correlation between $\delta^{18} \mathrm{O}_{\mathrm{ppt}}$ and MAT can be weak, the type of equation (local, regional or global), the regression method and the type of dataset (monthly or annual average precipitation data) that are used are significant factors which can significantly affect the palaeoclimatic interpretations (see Pryor et al., 2014 vs. Skrzypek et al., 2016). Accordingly, MAT values were calculated using different equations enabling a possible range of MAT values. The calculations were made with both Pryor et al.'s (2014) equation (based on meteorological and isotope data for Europe), and with an equation of Skrzypek et al. (2016), based on data for Italy. Combining the results of the two equations, estimated MAT values are $15.5 \pm 3.9{ }^{\circ} \mathrm{C}$ for level IX, $17.1 \pm 2.7{ }^{\circ} \mathrm{C}$ for level X, and $17.2 \pm 2.7^{\circ} \mathrm{C}$ for level XII. Because both recent day $\delta^{18} \mathrm{O}_{\mathrm{ppt}}$ (around $-5 \%$; Longinelli and Selmo, 2003) and MAT (16-17 ${ }^{\circ}$; ; Combourieu-Nebout et al., 2015) values are very similar to those calculated for levels X and XII, we can conclude that the climate at that time may have been close to that of today, whereas the climate in level IX may have been somewhat cooler.

\section{Conclusions}

Several rhinoceros remains from the imperfectly investigated lower levels (XII and XI) of the famous cave of Grotta Romanelli (Castro, Lecce, Italy) were described in this work. Whereas some of them do not display taxonomically diagnostic morphological characters, others (e.g., the astragalus and the metapodial bones) bear morphological features that can be referred to the middle Pleistocene species Stephanorhinus hundsheimensis (Toula, 1902). The Apulian area is indicated in the literature as a refuge for middle Pleistocene species which possibly survived there until the late Pleistocene. Nevertheless, Toula's rhinoceros became extinct in the Italian Peninsula long before the end of the middle Pleistocene; this suggests that the lower levels of Grotta Romanelli are older than previously reported. A middle Pleistocene age for these levels is also suggested by the presence of Hippopotamus antiquus as well as by the results obtained from the analysis of the volcanoclastic material collected from the bone surfaces. The stable isotope analyses $\left(\delta^{13} \mathrm{C}, \delta^{18} \mathrm{O}\right)$ on tooth fragments also revealed that the lower levels of the Cave deposited during more arid conditions compared to those of the well-known late Pleistocene level G ("Terre rosse deposit", chronologically referred to MIS 3). Accordingly, the Grotta Romanelli sequence is shown to span the early middle Pleistocene to Holocene time interval. In the light of these results, the age of the different mammal assemblages and associated lithic industries found in the cave and karst deposits of the Apulian area should be carefully revised. Unfortunately, there is no evidence that rhinoceros bones from Grotta Romanelli were burned by humans.

\section{Acknowledgments}

We are deeply grateful to P. Mazza, an anonymous reviewer, the associate editor P.-O. Antoine and the editor in chief G. Escarguel for their careful reading of the manuscript and for their useful comments and suggestions. L.P. thanks M. Gasparik (HNHM), E. Cioppi (IGF), O. Hampe (MfN), C. Sarti (MGGC), M. Fornasiero (MGPP), P. Pérez Dios (MNCN), C. Petronio and M.R. Palombo (MPUR), V. Montenegro and R. Francescangeli (MSTB), P. Brewer (NHML), U. Göhlich (NHMW), and L. Costeur (NMB) for their help and assistance during the visits to the rhinoceros fossil collections. L.P. also thanks C. Petronio for providing pictures of the specimens housed at MSNV. L.P. thanks the European Commission's Research Infrastructure Action, EU-SYNTHESYS project AT-TAF-2550, DETAF-3049, GB-TAF-2825, HU-TAF-3593, ES-TAF-2997. Part of this 
research received support from the SYNTHESYS Project (http:// www.synthesys.info/) which is financed by European Community Research Infrastructure Action under the FP7 "Capacities" Program.

\section{References}

Alessio, M., Bella, F., Cortesi, C., 1964. University of Rome carbon-14 dates. Radiocarbon 6, 77-90

Alessio, M., Bella, F., Bachechi, F., Cortesi, C., 1965. University of Rome carbon-14 dates III. Radiocarbon 7, 213-222.

Amiot, R., Lécuyer, C., Buffetaut, E., Fluteau, F., Legendre, S., Martineau, F., 2004. Latitudinal temperature gradient during the Cretaceous Upper CampanianMiddle Maastrichtian: $\delta^{18} \mathrm{O}$ record of continental vertebrates. Earth and Planetary Science Letters 226, 255-272.

Antoine, P.-O., 2002. Phylogénie et évolution des Elasmotheriina (Mammalia Rhinocerotidae). Mémoires du Muséum National d'Histoire Naturelle 188, 1-359.

Arzarello, M., Marcolini, F., Pavia, G., Pavia, M., Petronio, C., Petrucci, M., Rook, L. Sardella, R., 2006. Evidence of earliest human occurrence in Europe: The site of Pirro Nord (Southern Italy). Naturwissenschaften 94, 107-112.

Athanassiou, A., Bouzas, D., 2010. New Hippopotamid finds in Eurotas Valley (Laconia, Greece). Scientific Annals of the School of Geology, Aristotle University of Thessaloniki Proceedings of the XIX CBGA Congress, Thessaloniki, Greece special volume 99, 57-62.

Ayliffe, L.K., Lister, A.M., Chivas, A.R., 1992. The preservation of glacial-interglacia climatic signatures in the oxygen isotopes of elephant skeletal phosphate. Palaeogeography Palaeoclimatology Palaeoecology 99, 179-191.

Bella, F., Blanc, A.C., Blanc, G.A., Cortesi, C., 1958. La prima datazione con il ${ }^{14} \mathrm{C}$ della formazione pleistocenica di Grotta Romanelli (Terra d'Otranto). Quaternaria 5 $1-8$.

Binford, L.R., 1981. Bones: Ancient men and modern myths. Academic Press, New York320.

Blanc, G.A., 1920. Grotta Romanelli. Archivio per l'Antropologia e la Etnologia 50, 1 39

Blanc, G.A., 1928. Grotta Romanelli. Archivio per l'Antropologia e la Etnologia 58, 1 49.

Blanc, G.A., 1953. La Grotte Romanelli (Terre d'Otranto). In: Blanc, A.C., Segre, A.G. (Eds.), Excursion dans les Abruzzes, les Pouilles et sur la côte de Salerne. INQUA IV Congrès International, Roma-Pisa, pp. 35-47.

Blanc, A.C., 1955. Ricerche sul Quaternario Laziale, III. Avifauna artica, crioturbazioni e testimonianze di soliflussi nel Pleistocene medio-superiore di Roma e di Torre in Pietra. Il periodo glaciale Nomentano, nel quadro della serie di glaciazioni riconosciute nel Lazio. Quaternaria 2, 187-200.

Bökönyi, S., 1970. A New Method for the Determination of the Number of Individuals in Animal Bone material. American Journal of Archaeology 74, 291-292.

Bologna, P., Di Stefano, G., Manzi, G., Petronio, C., Sardella, R., Squazzini, E., 1994 Late Pleistocene mammals from the Melpignano (LE) "Ventarole": preliminary analysis and correlations. Bollettino della Società Paleontologica Italiana 33, 265-274.

Bryant, J.D., Froelich, P.N., 1995. A model of oxygen isotope fractionation in body water of large mammals. Geochimical and Cosmochimical Acta 59, 4523-4537.

Caloi, L., Palombo, M.R., Petronio, C., 1980. Resti cranici di Hippopotamus antiquus (= H. major) e Hippopotamus amphibius conservati nel Museo di Paleontologia dell'Università di Roma. Geologica Romana 19, 91-119.

Cardini, L., Biddittu, I., 1967. Attività scientifica dell'Istituto Italiano di Paleontologia Umana dalla sua fondazione, Liguria-Puglia. Quaternaria 9, 385-408.

Cardini, L., 1958. Prime determinazioni delle faune dei nuovi giacimenti costieri musteriani del Capo di Leuca. Quaternaria 5, 314-315.

Cassoli, P.F., Di Stefano, G., Tagliacozzo, A., 1999. I vertebrati dei livelli superiori (A e Alfa) della serie stratigrafica di Notarchirico. In: Piperno, M. (Ed.), Notarchirico. Un sito del Pleistocene medio iniziale nel Bacino di Venosa (Basilicata) 1. Ed. Osanna, Venosa, pp. 361-438.

Coltorti, M., Cremaschi, M., Peretto, C., Sala, B., 1980. Il Paleolitico inferiore nella Lombardi orientale, nel Veneto, nell'Emilia Romagna e nelle Marche. Atti XXII Rivista di Scienze Preistoriche, I.I.P.P. 123-146.

Combourieu-Nebout, N., Bertini, A., Russo-Ermolli, E., Peyron, O., Klotz, S., Montade, V., Fauquette, S., Allen, J., Fusco, F., Goring, S., Huntley, B., Joannin, S., Lebreton, V., Magri, D., Martinetto, E., Orain, R., Sadori, L., 2015. Climate changes in the central Mediterranean and Italian vegetation dynamics since the Pliocene. Review of Palaeobotany and Palynology 218, 127-147.

Corridi, C., 1987. Le faune pleistoceniche del Salento. 2 - La fauna di fondo Cattìe, Maglie Lecce. Quaderni del Museo Comunale di Paleontologia di Maglie 3, 5-74.

Dansgaard, W., 1964. Stable isotopes in precipitation. Tellus 16, 436e468. https:// doi.org/10.1111/j.2153-3490.1964.tb00181.x.

De Giuli, C., 1983. Le faune pleistoceniche del Salento 1. La fauna di San Sidero 3. Quaderni del Museo Comunale di Paleontologia di Maglie 1, 45-84.

De Giuli, C., Masini, F., Torre, D., 1987. The latest Villafranchian faunas of Italy. The Pirro Nord Fauna (Apricena Gargano). Palaeontographia Italica 74, 51-62.

Dettman, D.L., Kohn, M.J., Quade, J., Ryerson, F.J., Ojha, T.P., Hamidullah, S., 2001. Seasonal stable isotope evidence for a strong Asian monsoon throughout the past 10.7 m.y. Geology 29, 31-34.

Di Stefano, G., Petronio, C., 1997. Origin and evolution of the European fallow deer (Dama Pleistocene). Neues Jahrbuch für Geologie und Paläontologie Abhandlungen 203, 57-75.
Di Stefano, G., Petronio, C., Sardella, R., Savelloni, V., Squazzini, E., 1992. Nuove segnalazioni di brecce ossifere nella costa fra Castro Marina e Otranto (Lecce). Il Quaternario 5, 3-10.

Di Stefano, G., Petronio, C., Sardella, R., 1998. Biochronology of the Pleistocene mammal Faunas from Rome urban area. Il Quaternario 11, 191-199.

Domingo, L., Koch, P.L., Hernandez Fernandez, M., Fox, D.L., Domingo, M.S., Teresa Alberdi, M., 2013. Late Neogene and early Quaternary paleoenvironmental and paleoclimatic conditions in southwestern Europe: isotopic analyses on mammalian taxa. Plos One 8, e63739.

Fisher, W.J., 1995. Bone surface modifications in zooarchaeology. Journal of Archaeological Method and Theory 2, 7-68.

Fornaca-Rinaldi, G., Radmilli, A.M., 1968. Datazione con il metodo Th230/U238 di stalagmiti contenute in depositi mousteriani. Atti Della Società Toscana di Scienze Naturali 75, 639-646.

Fortelius, M., Mazza, P., Sala, B., 1993. Stephanorhinus (Mammalia: Rhinocerotidae) of the Western European Pleistocene, with a revision of S. etruscus (Falconer, 1868). Palaeontographia Italica 80, 63-155.

Freda, C., Gaeta, M., Giaccio, B., Marra, F., Palladino, D.M., Scarlato, P., Sottili, G., 2011. $\mathrm{CO}_{2}$ - driven large mafic explosive eruptions: a case study from the Colli Albani (central Italy). Bulletin of Volcanology 73, 241-256.

Gaudzinski, S., 1999. Middle Palaeolithic Bone Tools from the Open-Air Site Salzgitter-Lebenstedt (Germany). Journal of Archaeological Science 26, 125-141.

Giannandrea, P., La Volpe, L., Principe, C., Schiattarella, M., 2006. Unità stratigrafiche a limiti inconformi e storia evolutiva del vulcano medio-pleistocenico di Monte Vulture (Appennino meridionale Italia). Bollettino della Società Geologica Italiana $125,67-92$.

Guérin, C., 1980. Les rhinocéros (Mammalia Perissodactyla) du Miocène terminal au Pléistocène supérieur en Europe occidentale, comparaison avec les espèces actuelles. Documents des laboratoires de géologie de la Faculté des Sciences de Lyon 79, 3-1183.

Kahlke, H.D., 1977. Die Rhinocerotidenreste aus den Travertinen von Taubach. Quartärpaläontologie 2, 305-359.

Kahlke, R.D., 2001. Die Rhinocerotiden-Reste aus dem Unterpleistozän von Untermaßfeld. In: Kahlke, R.-D. (Ed.), Das Pleistozän von Untermaßfeld bei Meiningen (Thüringen), Teil 2. Mainz 40, Habelt, pp. 501-555.

Kocsis, L., 2011. Geochemical Compositions of Marine Fossils as Proxies for Reconstructing Ancient Environmental Conditions. Chimia 65, 787-791.

Koch, P.L., Tuross, N., Fogel, M.L., 1997. The effects of sample treatment and diagenesis on the isotopic integrity of carbonate in biogenic hydroxylapatite. Journal of Archaeological Science 24, 417-429.

Koch, P.L., 1998. Isotopic reconstruction of past continental environments. Annual Reviews of Earth and Planetary Science 26, 573-613.

Koenigswald, W., von Holly Smith, B., Keller, Th., 2007. Supernumerary teeth in a subadult rhino mandible (Stephanorhinus hundsheimensis) from the Middle Pleistocene of Mosbach in Wiesbaden (Germany). Palaeontologische Zeitschrift $81,416-428$.

Kohn, M.J., 2010. Carbon isotope compositions of terrestrial C3 plants as indicators of (paleo)ecology and (paleo)climate. Proceedings of the National Academy of Science U.S.A. 107, 19691-19695.

Kohn, M.J., Cerling, T.E., 2002. Stable isotope compositions of biological apatite. Reviews in Mineralogy and Geochemistry 48, 455-488.

Kotsakis, T., Abbazzi, L., Angelone, C., Argenti, P., Barisone, G., Fanfani, F., Marcolini, F., Masini, F., 2003. Plio-Pleistocene biogeography of Italian mainland micromammals. In: Reumer, J.W.F., Wessels, W. (Eds.), Distribution And Migration Of Tertiary Mammals In Eurasia. A Volume In Honour Of Hans De Bruijn, 10, DEINSEA, pp. 313-342.

Kovács, J., Szabó, P., Kocsis, L., Vennemann, T., Sabol, M., Gasparik, M., Virág, A., 2015. Pliocene and Early Pleistocene paleoenvironmental conditions in the Pannonian Basin (Hungary, Slovakia): Stable isotope analyses of fossil proboscidean and perissodactyl teeth. Palaeogeography, Palaeoclimatology, Palaeoecology 440, $455-466$.

Lacombat, F., 2005. Les rhinocéros fossiles des sites préhistoriques de l'Europe méditerranéenne et du Massif central Paléontologie et implications biochronologiques. BAR 1419, 1-175.

Lacombat, F. 2006. Morphological and biometrical differentiation of the teeth from Pleistocene species of Stephanorhinus (Mammalia, Perissodactyla, Rhinocerotidae) in Mediterranean Europe and Massif Central France. Palaeontographica Abt. A 274, 71-111.

Lazzari, A., 1955. Segnalazione di un livello di pomici in Grotta Romanelli, presso Castro (prov. di Lecce). Bolettino della Società dei Naturalisti in Napoli 64, 8392.

Lefèvre, D., Raynal, J.-P., Vernet, G., Kieffer, G., Piperno, M., 2010. Tephro-stratigraphy and the age of ancient Southern Italian Acheulean settlements: The sites of Loreto and Notarchirico (Venosa, Basilicata Italy). Quaternary International 223/224, 360-368.

Longinelli, A., Selmo, E., 2003. Isotopic composition of precipitation in Italy: a first overall map. Journal of Hydrology 270, 75-88.

Lyman, R.L., 1994. Vertebrate Taphonomy. Cambridge University Press, Cambridge552.

Marra, F., Pandolfi, L., Petronio, C., Di Stefano, G., Gaeta, M., Salari, L., 2014 Reassessing the sedimentary deposits and vertebrate assemblages from Ponte Galeria area (Rome, central Italy): an archive for the Middle Pleistocene faunas of Europe. Earth-Science Review 139, 104-122.

Martin, C., Bentaleb, I., Kaandorp, R., Iacumin, P., Chatri, K., 2008. Intra-tooth study of modern rhinoceros enamel $\delta^{18} \mathrm{O}$ : Is the difference between phosphate and 
carbonate $\delta^{18} \mathrm{O}$ a sound diagenetic test? Palaeography, Palaeoclimatology, Palaeoecology 266, 183-189.

Mastronuzzi, G., Quinif, Y., Sansò, P., Selleri, G., 2007. Middle-Late Pleistocene polycyclic evolution of a stable coastal area (souther Abulia Italy). Geomorphology 86, 393-408.

Mazza, P., Varola, A., 1999. Revision of the Middle Pleistocene rhinoceros remains from Contrada Monticelli (Castellana, Bari Southern Italy). Il Quaternario 12, 99-104.

Mazza, P., 1995. New evidence on the Pleistocene hippopotamuses of Western Europe. Geologica Romana 31, 61-241.

Mecozzi, B., Iurino, D.A., Berte, D.F., Sardella, R., 2017. Canis mosbachensis (Canidae, Mammalia) from the Middle Pleistocene of Contrada Monticelli (Putignano Apulia, southern Italy). Bollettino della Società Paleontologica Italiana 56, 72.

Metcalfe, J.Z., Longstaffe, F.J., 2012. Mammoth tooth enamel growth rates inferred from stable isotope analysis and histology. Quaternary Research 77, 424-432.

Milli, S., Palombo, M.R., 2005. The high-resolution sequence stratigraphy and the mammal fossil record: a test in the Middle-Upper Pleistocene deposits of the Roman Basin (Latium, Italy). Quaternary International 126/128, 251-270.

Mirigliano, G., 1941. Avanzi di vertebrati quaternari di Melpignano (Lecce). Atti della Reale Accademia delle Scienze fisiche e matematiche di Napoli S. III 2, 1 46.

Palladino, D.M., Gaeta, M., Giaccio, B., Sottili, G., 2014. On the anatomy of magma chamber and caldera collapse: the example of trachy-phonolitic explosive eruptions of the Roman Province (central Italy). Journal of Volcanology and Geothermical Research 281, 12-26.

Palombo, M.R., Milli, S., Rosa, C., 2004. Remarks on the late Middle Pleistocene biochronology on the mammalian faunal complexes of the Campagna Romana. Geologica Romana 37, 135-143.

Pandolfi, L., Petronio, C., 2011a. The small-sized rhinoceroses from the Late Pleistocene of Apulia (southern Italy). Rivista Italiana di Paleontologia e Stratigrafia 117, 509-520.

Pandolfi, L., Petronio, C., 2011b. Stephanorhinus etruscus (Falconer, 1868) from Pirro Nord (Apricena Foggia, Southern Italy) with notes on the late Early Pleistocene rhinoceroses of Italy. Rivista Italiana di Paleontologia e Stratigrafia 117, 173 187.

Pandolfi, L., Tagliacozzo, A., 2013. Earliest occurrence of wooly rhino (Coelodonta antiquitatis) in Italy (Late Pleistocene Grotta Romanelli site). Rivista Italiana di Paleontologia e Stratigrafia 119, 125-129.

Pandolfi, L., Marra, F., 2015. Rhinocerotidae (Mammalia Perissodactyla) from the chrono-stratigraphically constrained Pleistocene deposits of the urban area of Rome (Central Italy). Geobios 48, 147-167.

Pandolfi, L., Petronio, C., 2015. A brief review of the occurrences of Pleistocene Hippopotamus (Mammalia Hippopotamidae) in Italy. Geologica Croatica 68, 313-319.

Pandolfi, L., Tagliacozzo, A., 2015. Stephanorhinus hemitoechus (Mammalia, Rhinocerotidae) from the Late Pleistocene of Valle Radice (Sora Central Italy) and reevaluation of the morphometric variability of the species in Europe. Geobios 48, 169-191.

Pandolfi, L., Erten, H., 2017. Stephanorhinus hundsheimensis (Mammalia, Rhinocerotidae) from the late early Pleistocene deposits of the Denizli Basin (Anatolia Turkey). Geobios 50, 65-73.

Pandolfi, L., Gaeta, M., Petronio, C., 2013. The skull of Stephanorhinus hemitoechus (Mammalia, Rhinocerotidae) from the Middle Pleistocene of Campagna Romana (Rome Central Italy): biochronological and paleobiogeographic implications. Bulletin of Geosciences 88, 51-62.

Pandolfi, L., Grossi, F., Frezza, V., 2015. New insights into the Pleistocene deposits of Monte delle Piche, Rome, and remarks on the biochronology of continental Hippopotamus (Mammalia Hippopotamidae) and Stephanorhinus etruscus (Mammalia, Rhinocerotidae) in Italy. Estudios Geologicos 71, e026.

Pandolfi, L., Cerdeño, E., Codrea, V., Kotsakis, T., 2017a. Biogeography and chronology of the Eurasian extinct rhinoceros Stephanorhinus etruscus (Mammalia Rhinocerotidae). Comptes Rendus Palevol 16, 762-773.

Pandolfi, L., Mannino, M.A., Talamo, S., Salari, L., Sansò, P., Sublimi Saponetti, S., Vacca, E., Vicari, D., Richards, M.P., Petronio, C., 2017b. A reassessment of the infills and faunal assemblages of karst cavities known as ventarole in Salento (Apulia, Southern Italy): a multidisciplinary investigation on Cava Donno (Corigliano d'Otranto Lecce). Alpine and Mediterranean Quaternary 30, 25-40.

Pellegrini, M., Lee-Thorp, J.A., Donahue, R.E., 2011. Exploring the variation of the delta O-18(p) and delta O-18(c) relationship in enamel increments. Palaeogeography, Palaeoclimatology, Palaeoecology 310, 71-83.

Petronio, C., Bellucci, L., Martinetto, E., Pandolfi, L., Salari, L., 2011. Biochronology and Palaeoenvironmental Changes from the Middle Pliocene to the Late Pleistocene in Central Italy. Geodiversitas 33, 485-517.
Petronio, C., Di Canzio, E., Salari, L., 2007. The Late Pleistocene and Holocene Mammals in Italy: new biochronological and paleoenvironmental data. Palaeontographica, Abt. A 279, 147-157.

Petronio, C., 1986. Nuovi resti di ippopotamo del Pleistocene medio-inferiore de dintorni di Roma e problemi di tassonomia e filogenesi del gruppo. Geologica Romana 25, 63-72.

Petronio, C., 1995. Note on the taxonomy of Pleistocene hippopotamuses. Ibex 3 , 53-55.

Pirrone, C.A., Buatois, L.A., Bromley, R.G., 2014. Ichnotaxobases for Bioerosion Trace Fossils in Bones. Journal of Paleontology 88, 195-203.

Pokines, J., Symes, S.A., 2013. Manual of Forensic Taphonomy. CRC Press, 496.

Pryor, A.J.E., Stevens, R.E., O'Connell, T.C., Lister, J.R., 2014. Quantification and propagation of errors when converting vertebrate biomineral oxygen isotope data to temperature for palaeoclimate reconstruction. Palaeogeography, Palaeoclimatology, Palaeoecology 412, 99-107.

Ravazzi, C., Pini, R., Breda, M., 2009. Reconstructing the palaeoenvironments of the Early Pleistocene mammal faunas from the pollen preserved on fossil bones. Quaternary Science Review 28, 2940-2954.

Rozanski, K., Araguás-Araguás, L., Gonfiantini, R., 1993. Isotopic Patterns in Modern Global Precipitation. In: Swart, P.K., Lohmann, K.C., Mckenzie, J., Savin, S. (Eds.) Climate Change in Continental Isotopic Records. American Geophysical Union, Washington, DC, pp. 1-36.

Rustioni, M., Mazza, P., Abbazzi, L., Delfino, M., Rook, L., Petrucci, S., Vianello, F. 1994. The würmian fauna from Sternatia (Lecce, Apulia Italy). Bolletino Società Palentologica Italiana 33, 279-288.

Sala, B., 1980. Faune a grossi vertebrati nel Pleistocene superiore vertebrati fossili italiani I. Catalogue of the exibition Verona 235-238.

Sardella, R., Mazzini, I., Giustini, F., Mecozzi, B., Brilli, M., Iurino, D.A., Lembo, G. Muttillo, B., Massussi, M., Sigari, D., Tucci, S., Voltaggio, M., 2018. Grotta Romanelli (Southern Italy Apulia): legacies and issues in excavating a key site for the Pleistocene of the Mediterranean. Rivista Italiana di Paleontologia Stratigrafia 124, 247-264.

Schreiber, H.D., 2005. Osteological investigations on skeleton material of rhinoceroses (Rhinocerotidae, Mammalia) from the early Middle Pleistocene locality of Mauer near Heidelberg (SW-Germany). In: Crégut-Bonnoure, E. (Ed.), Les Ongulés Holarctiques du Pliocène et du Pléistocène, 2, Quaternaire (H.-S.), pp. 103-111.

Shipman, P., Foster, G., Schoeninger, M., 1984. Burnt bones and teeth: an experimental study of color, morphology, crystal structure and shrinkage. Journal of Archeological Science 11, 307-325

Skrzypek, G., Sadler, R., Wiśniewski, A., 2016. Reassessment of recommendations for processing mammal phosphate $\delta^{18} \mathrm{O}$ data for paleotemperature reconstruction. Palaeogeography, Palaeoclimatology, Palaeoecology 446, 162-167.

Sottili, G., Palladino, D.M., Gaeta, M., Masotta, M., 2012. Origins and energetics of maar volcanoes: examples from the ultrapotassic Sabatini Volcanic District (Roman Province Central Italy). Bulletin of Volcanology 74, 163-186.

Stiner, M.C., Kuhn, S.L., Weiner, S., Bar-Yosef, O., 1995. Differential burning, recrystallization, and fragmentation of archaeological bone. Journal of Archaeological Science 22, 223-237

Tagliacozzo, A., 2003. Archeozoologia dei livelli dell'Epigravettiano finale di Grotta Romanelli (Castro, Lecce) strategie di caccia ed economia di sussistenza. In: Fabbri, P.F., Ingravallo, E., Mangia, A. (Eds.), La Grotta Romanelli nel centenario della sua scoperta (1900-2000). Atti del Convegno Castro 6-7 ottobre 2000, pp. 169-216.

Tafforeau, P., Bentaleb, I., Jaeger, J.-J., Martin, C., 2007. Nature of laminations and mineralization in rhinoceros enamel using histology and X-ray synchrotron microtomography: Potential implications for palaeoenvironmental isotopic studies. Palaeogeography, Palaeoclimatology, Palaeoecology 246, 206-227.

Tipple, B.J., Meyers, S.R., Pagani, M., 2010. Carbon isotope ratio of Cenozoic CO2: A comparative evaluation of available geochemical proxies. Paleoceanography 25 , PA3202.

van der Made, J., 2010. The rhinos from the Middle Pleistocene of Neumark-Nord (Saxony-Anhalt). Veröff. L-amt. Archäol. 62, 432-527.

Vennemann, T.W., Fricke, H.C., Blake, R.E., O'Neil, J.R., Colman, A., 2002. Oxygen isotope analysis of phosphates: a comparison of techniques for analysis of $\mathrm{Ag}_{3} \mathrm{PO}_{4}$. Chemical Geology 185, 321-336.

Vialli, V., 1956. Sul rinoceronte e l'elefante dei livelli superiori della serie lacutre di Leffe (Bergamo). Memorie della Società Italiana di Scienze Naturali 12, 1-71.

Villa, I.M., Buettner, A., 2009. Chronostratigraphy of Monte Vulture volcano (southern Italy): secondary mineral microtextures and ${ }^{39} \mathrm{Ar}-{ }^{40} \mathrm{Ar}$ systematics. Bulletin of Volcanology 71, 1195-1208.

Vogel, J.C., Waterbolk, H.T., 1963. Groningen radiocarbon dates IV. Radiocarbon 5, $163-202$. 